Portland State University

PDXScholar

$11-19-1976$

\title{
The Effect of Visual Feedback on Vocal Pitch Matching
}

Anita R. Herron

Portland State University

Follow this and additional works at: https://pdxscholar.library.pdx.edu/open_access_etds

Part of the Music Commons, and the Psychology Commons Let us know how access to this document benefits you.

\section{Recommended Citation}

Herron, Anita R., "The Effect of Visual Feedback on Vocal Pitch Matching" (1976). Dissertations and Theses. Paper 4043.

https://doi.org/10.15760/etd.5927

This Thesis is brought to you for free and open access. It has been accepted for inclusion in Dissertations and Theses by an authorized administrator of PDXScholar. Please contact us if we can make this document more accessible: pdxscholar@pdx.edu. 
AN ABSTRACT OF THE THESIS OF An1to R. Herton for the Master of Science in Psychology presented November 19, 1976.

IItle: The Etfect of Visual Feedback on Vacal Pifch Matching. APPROVED BY MEMBERS OF THE THESIS COMMITIEE:
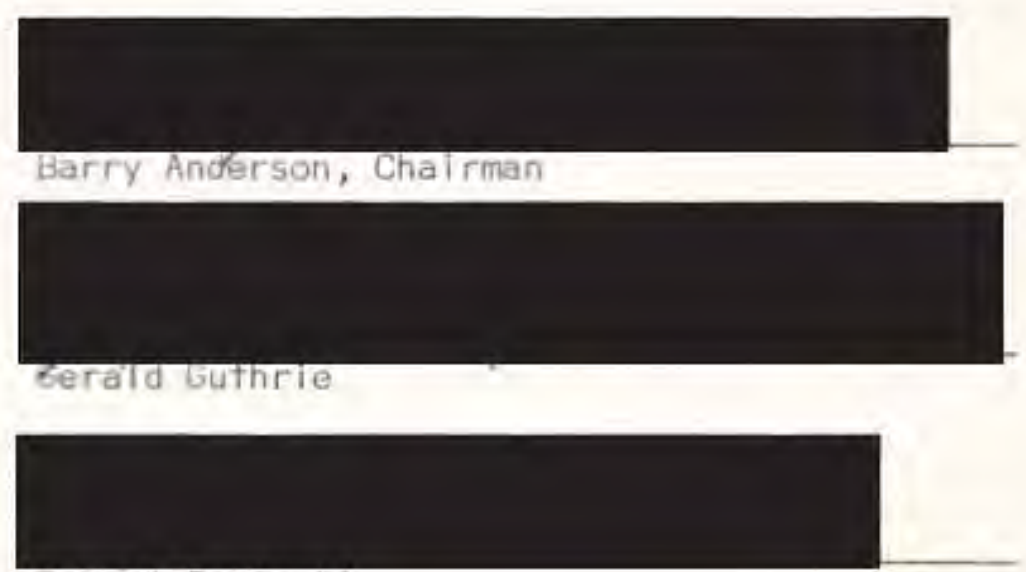

Robert Powloski

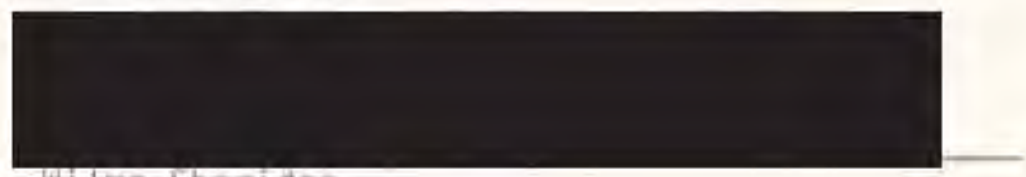

Wilma Sheridan

A review of the literature on the inaccurate singer provided strong evidence that improvement in pifch matching skill was possible. Wisual teedback was found to be an efteetive aid in earlier studies, but none of the previous studies provided both a comparison group Which had identical practice without the visual cues and a control group which recelved no form of practice. Such a design was used in the present study. 
Thirty students at Portland State University who claimed to have considerable difficulty carrying a tune were given the opportunity to try to match individual pitches under one of three conditions to which they were randomly assigned. The two experimental groups (I and II) had a period of about $45 \mathrm{ml}$ nutes to practice matching a prerecorded model of each of the eight notes of the $C$ major scale. There were nine trials per note. Group 1 I received additional feedback from a Stroboconn, which provided visual information on accuracy or degree and direction of error. Group 111 was the control and had no training period. All subjects' initial pitch matching abillty was assessed, and all subjects took a posttest.

The results on pitch matching were not as expected. Analyses of covariance showed that there were no significant effects of practice in general and no significant differences between the two experimental conditions.

The results of self-evaluation, based on interviews given after the posttest, showed that some subjects tended to improve their opinion of their pitch matching ability. This was significant, though only with a one-tailed test $(z=1.74, p<.05)$. It thus seems that even a brief opportunity to try out this skill in a relatively non-threatening setting can begin to reverse a lifelong negative selt-assessment.

It is speculated that the experiment was too brief to allow the subjects in the Visual group to take full advantage of the stroboconn. In addition, results of the preliminary assessment measure showed that the tasks may have been too easy for the majority of the subjects, who despite having difficulty carrying a tune, were not severely deficient in their ability to match individual pitches. 
THE EFFECT OF VISUAL FEEDBACK

ON VOCAL PITCH MATCHING

by

ANITA R. HERRON

A thesis submitted in partial fulfilliment of the requirements for the degree of

\section{MASTER OF SCIENCE \\ in \\ PSYCHOLOGY}

Portland State University

1976 
TO THE DIFICE OF GRADUATE STUDIES MD RESEAICH!

The members of the Comblttee approve the thesis of

Anlta R. Herron presented Novmeder 10, 1976.
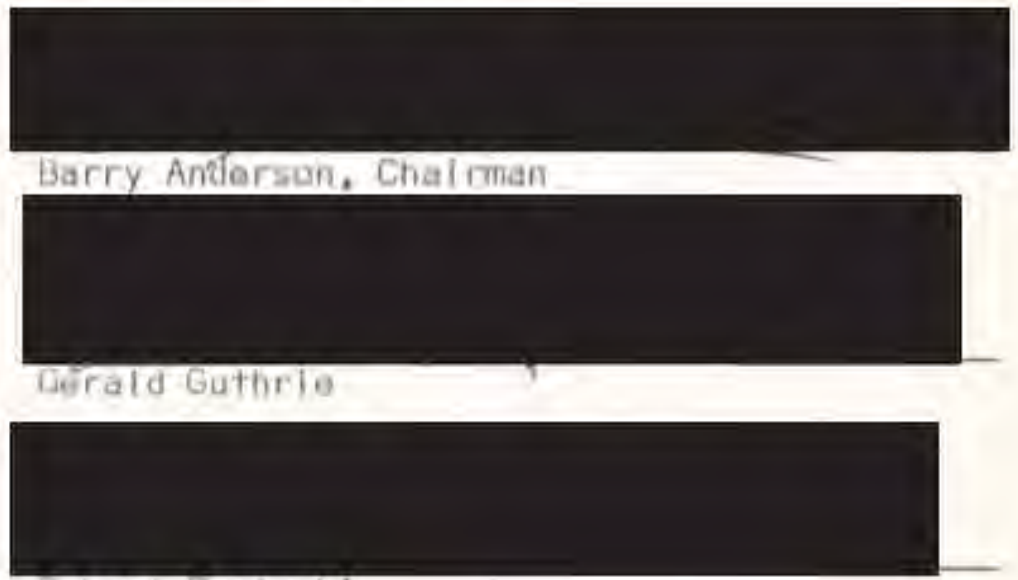

Robert Pow Ioski

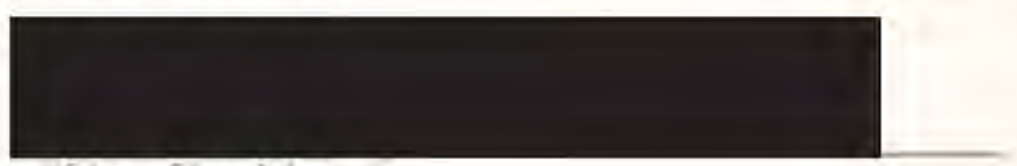

Wime Sharidan

APFRQVEO:

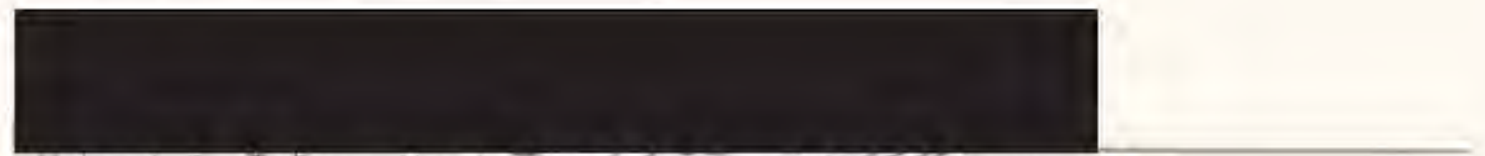

Robert E. Johes, Head, Depaptment of Alychology

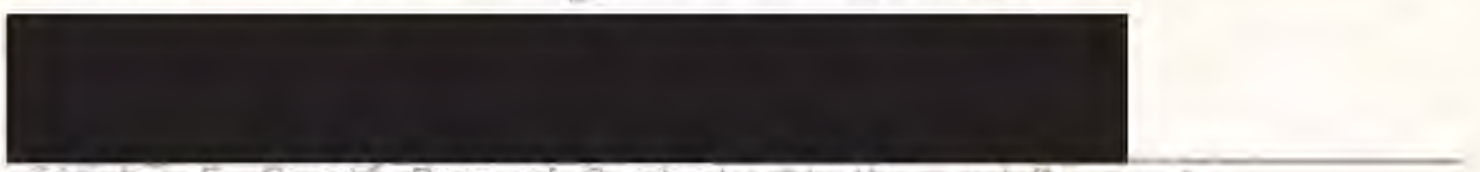

Fanter E. Raoch, Dean of Graduate Studies and Revesr ch

hevamber 19. 1976 


\section{ACKNOWLEDGMENTS}

Special thanks are due the members of my committee, Barry Anderson, Robert Powloski and Gerald Guthrie, who generously offered their time and provided important guidance in research design and methodology. Their continued encouragement and support were much appreciated.

In addition, I would like to express my gratitude tor the time and advice given by other members of the Departments of Psychalogy, Music, and Speech and Hearling Sciences, and by individuals in the Learning Laboratory and Audio-Visual Services.

Appreciation must also go to all of those friends and students who, desplte uncertainty about their voices, volunteered to sing for the pilot studies or the actual experiment. 
TABLE OF CONTENTS

PAGE

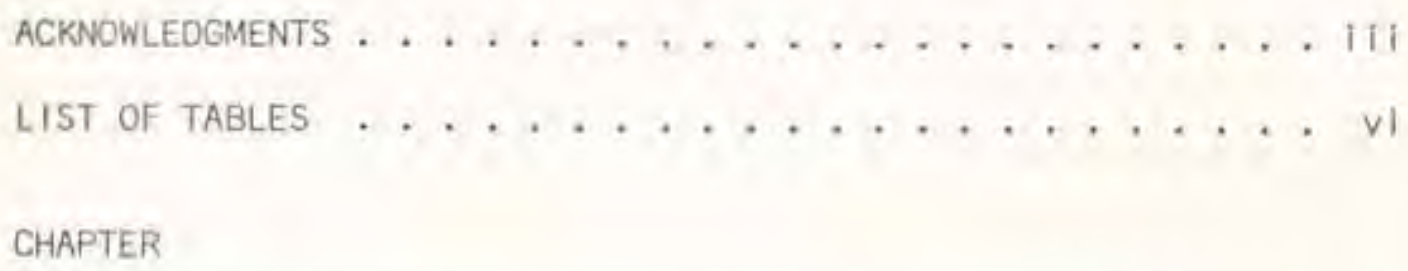


PAGE

CHAPTER

VI DISCUSSION ........................... 37

Comparison of Groups . . . . . . . . . . 37

Physiological Traits and Performances.... . 38

Interviews ............ 40

VII CONCLUSIONS AND RECOMMENDATIONS ........ 43

SELECTED BIBLIOGRAPHY .................. 48

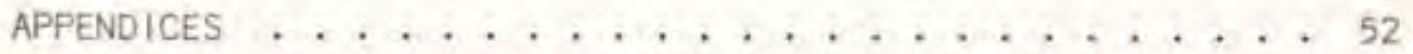

A AVERAGED SCORES: JUDGE A AND JUDGE $K \ldots \ldots 2$

B AVERAGED GROUP MEANS AND STANDARD DEVIATIONS:

JUDGE A AND JUDGE $K \ldots \ldots . \ldots . \ldots$

C ACCURACY SCALES ..................... 55

D INTERVIEW: SUGGESTED QUESTIONS ......, . 56

E TRAINING PROCEDURE AND POSTTEST: TRANSCRIPTS OF

TAPED INSTRUCTIONS, TYPED INSTRUCTION CARDS, CHARTS ..................... 58

F PHOTOGRAPH OF STROBOCONN .......... 74

6 RANIS ON AUDIOGRAMS AND PRESCORES ....... 75 


\section{LIST OF TABLES}

TABLE

PAGE

I Scoring PIan with Group Means and Standard

Deviations ............. 29

II Non-visual vs. Visual vs. Control Conditions:

Comparison of Anova and Ancova for Posttest . . . . 31

111 Non-visual vs. Visual Conditions: Comparison

of Anova and Ancova for Training Procedure..... 31 
CHAPTER ।

INTRODUCTION

Music teachers have been striving throughout this century and probably long betore to help people learn to sing in tune. Remedial Instruction has often been given in an effort to enable the inaccurate singer to partlcipate in music with his peers or to help alleviate the disruption caused by the "monotone, growler, grunter, droner" (Bentlay, 1968, p.683. In the literature these people have been called "bockward s) ngers," "tonedeaf," "uncertain singers," and "out-of-tune singers" In addition to the four descriptive names cited by Bentley. In the present study, however, the term "inaccurate singer" will be used and defined as follows: someone who consistently is unable to sing at the unison with another volce or instrument of the same pitch range, or, as Joyner $(1969, \mathrm{p}, 115)$ describes it, one who "consistently fails to reproduce the tonal configuratlon of a melody in a recognizable manner."

\section{DEFINITION OF THE AREAS}

Several aspects of the problem of the inaccurate singer will be examined, including evidence on how the ability to carry a tune develops under normal circumstances and what kinds of factors may characterize the inaccurate singer. Investigators of this problem, in seeking to ascertain just what aspects of musical ability are related to 4

difficulty in carrying a tune, have focussed on pitch discrimination 
(PO), pitch reproduction (PR) and tonal memory. They have sought to al leviate the difficulfy by emphasizing one or more of these skills in a remedial training program, by which means they hoped to disprove early pronouncements that the condition was not improvable. Being teachers as well as researchers, the investigators have sometimes sacrificed clarity of experimental design in order to provide individualized instruction. The remedial training has usually combined practice with one or more forms of feedback, although in rare cases no external knowledge of results (KR) was provided. Since the present study is concerned with the effect of visual feedback in particular, the literature in this area will be the one most thoroughly revlewed. 
CHAPTER II

\author{
REVIEW OF THE LITERATURE \\ 1. DEVELOPMENT OF THE AEILITY TO CARRY A TUNE
}

Some ablilty to discriminate pitches is present even at birth (Bridger, 1961). Without specific training, between the ages of two and ten the child gradually increases his vocal pitch range SWerner, 1973; Jersild and Bienstock, 1934) and at least up to age 14 is still in the process of developing his ability to carry a tune Bentley, 1968) and discriminate pitches (Meissner, cited in Werner, 1973, p.101). A positive relationshlp has been found between singling ablitity and the home environment, including such aspects as the fact that the mother sings and/or plays piano, there is music heard, played or appreciated (Reynolds, 1960; Rainbow, 1965; Updegraff, 1938), and there are cultural and socio-economic advantages (Kirkpatrick, 1962).

Some studles have pointed to the negatl ve effect of certaln school experiences on singing. A child who has not yet reached the stage developmentally where he can sing accurately may be teased by peers or told not to sing by a teacher, making it more difficult for film to overcome the problem (McNitH, 1971). Boys, who have a much higher incidence of this problem (Bentley, 1968) may feel that singing Is for sissies when in grade school (Bentley, 1968) or be embarrassed to sing during the time their volces are changing, and thus withdraw from the very musical experiences that might provide the ear training, 
practice In coordination of ear and voice, and flexibility of vocal cords necessary to become accurate singers (Ekstrom, 1959; Swanson, 1959). This has a circular effect later, since the difficulty in singing tends to lead to discouragement and lack of confidence to try to improve (MCNitt, 1971).

\section{INACCURATE SINGERS: CHARACTERISTICS}

\section{Physiological}

Individual differences in the physiology of the ear, vocal cords and nervous system do exist, of course, and some of these are likely to affect one's limlt of ability. However, there has been little strong evidence to show just how these factors interact in singing, or at what point one can be sure someone has reached that limit, or whether further training of an appropriate kind could still stretch the apparent limit (Farnsworth, 1938). In rare cases an inaccurate singer has a hearing problem like displacusis Cexperlencing a single pitch as different in two ears) rather than a deficit in hearing acuity (Cuipepper, 1961; Bentley, 1968; Farnsworth, 1938). However, people with displacusis may also be normal singers (Powell, 1969). Since even so-called "tonedeaf" people usually make and distinguish pitch fluctuations (Abercrombie, 1967) it appears more likely that the problem lles in other areas than the physiology of the ear.

\section{Cognitive}

Partly due to the difficulty of assessing physiological and especiolly neurological differences, many workers have looked most closely at the cognitive aspects of the probiem. Relying in part on 
introspective reports of subjects and in part on experimental data, they have examined the importance of memory and infelligence in pitch reproduction (PR) and pitch discrimination (PD).

Intelligence. A thorough review of the pre-1968 research by Shuter in The Psychology of Musical Abllity (1968), revealed much evidence that $1 Q$ is not a significant factor in inaccurate singing or pitch discrimination or tonal mamory, except perhaps when the if is under 90 ,

Relationships Among Pitch Discrimination, Pitch Reproductlon and Tonal Memory. Much of the early literature deals with improvement in PO rather than PR. Therefore before the remedial training methods are descrlbed, the evidence will be examinnd that PD and PR are related, and that the latter is related to tonal memory as well. Some of the studies show a strong positive correlation, some have non-significant results, but none shows a negative relationshlp, except for isolated cases (Wing, 1968). Bentley (1968), in revlewing the British literature on "monotones" noted the following studies:

1) Fieldhouse in 1937 found a barely significant difference between means on PD tests when comparing 50 young "backward singers" with 96 controls. However, he found a highly significant difference between means on a memory test.

2) Fry in 1948, testing 1200 subjects age 11 and up, found a close association between tonal memory as measured by Seashore's 1919 tonal memory test and Fry's own "distorted memory test," on which the subject was to say which of a pair of melodic phrases from familiar tunes had wrong notes in it. Fry defined as tonedeaf those five percent who could not meet the criterion on his distorted melody test, 
rather than use any independent measure such as music teachers' rating, as was done by many of the other investigators. Fry did not tind a significant correlation between tonedeatness and PD, but it should be kept in mind that he had no measure of his subjects' ability to match pitches vocally.

Bentley (1968) reports results of several broad surveys of 18,000 children ages 7-13 which he did in 1954-1957. On the basis of teachers' identification of monotones, or those who persistently sing out of tune, he found four to four-and-a-half percent were classified as monotones, closely approximating the five percent found by Fry as described above (Bentley, 1968). From the monotones Bentiey randomly selected 88 subjects and then selected 312 normal singers of comparable socio-economic and domestic environments, who had had similar classroom music lessons. He found a significant difference between means In tonal memory and PD between normal and monotone singers. These results were also found in two later studies.

Shuter (1968) ralses the possibility that these singers have some interference in retrievol of melody rather than a problem of storage. She polnts to Wilder Penfleld's experiments with stimulating the brain ouring operations for epllepsy. He found that some patients had vivid recall of past musical events and could hum in detail particular pieces that they had heard earlier and heard again as a result of mild electrical stimulation to the brain (Penfield, cited in Shuter, 1968, p,20s). Pedersen and Pedersen (1970) tested two 5th grade classes in two different years, using their own PD test and vocal reproduction test, both of which used tones produced by plano. For group 11 there was a correlation between the two tests significant beyond the .01 level; 
for group I the correlation was significant beyond the .05 level.

In 1968 and 1971 Joyner (clted in Roberts and Davies, 1975) tested groups of monotones and a group of normal children at each of five age levels, using pure tones. He found that the pure monotones were signiflcantly worse than normals at PD, but those who could sing funefully at low pitches were not worse at PD.

In her 1971 study of 100 first graders identified as accurate and Inaccurate singers by their classroom teachers and by a vocal test, Zwissler (1971) found the inaccurate had significantly lower scores on PD.

Thus a majority of the research shows a relationship between Inaccurate singing and PD. The non-significant results that were reported may have been a function of the tests used rather than of the ability itself, since the tests were often unstandardized instruments designed by the investigators for particular research projects. The literature on remedial Instruction, reviewed below, gives some further evidence on the connection, showing that improvement in PR transfers to PD (Cameron, 1917) and the reverse (Capurso, 1934).

\section{Emotional}

Although some studies have reported a correlation between inabilIty to carry a tune and maladjustment or low self-esteem (Rarm, 1947; Greenberg, 1970), the evidence seems unreldable since there were no control groups of normal singers testes on the personalify measures at the same time. 
111. INACCURATE SINGERS: IMPROVABILITY

Issues

The Improvability Controversy. The aim in many of the early studies was to disprove C. E. Seashore's statements (1938, p. 58):

The physiological limit for heoring pitch does not improve with training.... Tralning probably does not modlty the capacity of the sense organ any more than the playlng of the good violin may improve the quallty of its tone.

Seashore had made similar remarks as early as 1910 and his influence In the field of the psychology of music was so important during the flrst 40 years of this century that his ideas stimulated much research. The above statements were interpreted to mean, for example, that people who did poorly on a Seashore PD test as adults were classed as untrainable. It should be noted, however, that Seashore (1910) did not oliminate the possibility that a test at any time might be tapping the functional, but not the physiological limit, and that the former could increase with training. Indeed, much of this early research did stiow Improvement in PD ablility.

The Teacher-Researcher Conflict. In reviewing the literature on the Inaccurate or "uncertal $n$ " singer, one becomes immediately aware of a conflict between teaching and research: because of individual differences. the most effective method for Improving PR in one person may be too easy, too difficult, or otherwise inappropriate for another person. In many of the studies, especlally the early ones, the Investigators chose to emphaslze training rather than experimental design, as they adjusted their remedial techniques to fit individual needs. While this seemed to be most helptul to the subjects in any given study, it did not provide clear guldellnes for later teachers or 
psychologists. Frequently the actual methods of training were glossed over in a report, while the pre- and post-tests, the subjects' introspective comments on what helped them Improve, and the degree of Improvement were highlighted. Some studies used as subjects those who did worst on the pretest. Others used an unclassifled sample and then noted the effect of trainlng on those who performed least well on the pretests.

Some recent workers, more aware of the requirements for good scientific research, have tried, for example, to control subject and treatment varlables, carefully quantify independent and dependent variables, and use sophisticated tests of significance. This sometimes leads to statistically non-significant results. However, closer examination of trends within subjects sometimes reveals important leads: concerning a treatment whose effects were highly successful for some Individuals, but not necessarily overall. Such skewed results suggest the noed to investigate further the individual differences that are present in the samples. Thus we are back at the original dilemna: how can one do good research and yet get results whlch wlll have wide applicablitity?

Remedial Training Methods. Although most studies up to now have not reported universal suocess with any single treatmont, many have demonstrated the effectiveness of a large variety of techniques which they used on various samples of singers.

\section{Non-visual Methods.}

Most of the studies reviewed reported the successful fraining of inaccurate singers by means of a comblmation of practice and some kind 
of feedback which supplemented the hearing of one's own voice. The feedback Included verbal comments on accuracy (Connette, 1941; Knock, 1922; Leontiev, 1957; R. H. Seashore, 1935), observed changes in the larynx (kinesthetic cues) reported by Wyatt (1945), Vernon (1934-35), Mainwaring (1933), Smith (1914) and R. H. Seashore (1935), the simultaneous accompaniment af an accurate model singing or playing the same pitch, and additional sounding of the pitch on one or another instrument or voice between vocal trials (Wyatt, 1945). Practice was also aided in the following ways: imagining the pitch before singing it (Wyatt, 1945) and using earphones to help focus attention and possibly compensate for any pertial nerve damage by making use of bone conduction (Leontiev, 1957; Moss, 1973).

Practice alone. In contrast to the studies cited above, two studies were reviewed which reported improvement even though no knowledge of results (KR) was provided the subjects, When Greenberg (1970) placed 10 young inaccurate slingers into a grade school chorus at their request, he found that six of them Improved considerably although they had been given no special attention. This suggests that their motivafion and the opporfunity to participate in singing activities without belng singled out as different played important roles. Wright (1928) found improvement from practice alone. While practicing the Seashore PO test for one hour dally for five consecutive days, the six adults who had originally scored lowest steadily improved, moving from an average of the 43 rd percentile to the 82 nd percentile.

Thorndike's work on KR reported in Fundamentals of Learning (1932), suggested that practice without KR is likely to be ineffective, so one might wonder how these subjects in Wright's study improved at 
all. It is important to consider the possibility that they recelved sutficlent KR during practice just through their own ears. Evidence for such internal KR was found in 1941 by H. Seashore and A. Bavelas. They looked closely at the data from Thorndike's original line drawing experiment where the subject tried to draw a $4^{\prime \prime}$ II ne wlth eyes closed, never seeing the results, using 3000 trials, and found that al though the subject had not gotten any closer to the $4^{\prime \prime}$ line he was supposed to draw, he did come increasingly closer to his own average of 5.01 ", suggesting to these authors $(p .161)$ that

even erroneous conceptions of what is occurrling in his performances constitute part of his KR.... Remembered experiences (ideational or motor) and current sensory data, operating on an alert, well-motivated person, are variables which should enable him to learn, even though he has no objective evidence from other persons or by selif-measurement with which to check. himself.

This kind of internal KR should be kept in mind as a possible source for improvement In the non-visual condition of the present experiment.

\section{Visual Methods}

One method which has been shown to be particularly effective in music training Is visual feedback, when used as an accessory cue to the auditory experiences of the subject (hearing his own vocal or instrumental pitch). Workers in perception and psychophyslcs have given considerable aftention to the facibltating effect of auxillary auditory stimuli on visual perception and the reverse (Seif and Howard, 1975; Bornstein, 1970).

Training Instrumentalists. A 1972 study by Guerin looked at the effect of three feedback modes on the intonation of 36 grade school 
clarinetists and trumpeters. After four days of training on five of seven pitches for a total of one hour per subject, the group given visual feedback from the Stroboconn (an electronic stroboscopic device which gives immediate indication of which pitch is being sung into its microphone, and whether that pltch is accurate, sharp or flat) in addition to belng able to hear their own intonation improved most on the two untrained pitches, which seems strange, but no group improved significantly on the trained pitches. Here one reason group averages may not have reflected change was the presence of vast differences at the start. In addition, training was very brief. Guerin did look at individual performances, however, and found that those who were initialIy worst improved most regardless of treatment, suggesting that practice With any KR and perhaps the extra attention alone has some positive iffect, especially on the poorest group.

Training singers. In training singers to more accurately match pitches, several visual methods have proved successful. As early as 1910 C. E. Seashore found the tonoscope (a mechanloal device that automatically showed the singer the degree and direction of error in a visual representation) to aid in improving the "voluntary control of the pitch of the volce" (p.318). His 6 adult male subjects practiced singing particular tones and intervals 45 minutes daily for 12 days in the following way: five days without visual ald, five days with aid, the 11 th day tested without ald, the 12 th day tested with visual aid. Although the design was not counterbalanced, the records for the series with aid were on a distinctly different level than for the series without aid, and evidence of gain within each series was not pronounced, so the initial immediate effect of the visual aid was striking. 
Heller (1969) used electronic graphs produced by a strip chart recorder to give immediate, continuous visual feedback on pitch matching. His subjects were 12 college muslc majors. There were two conditions. In both groups the subjects heard the model singing a purposely distorted familiar tune in one ear and heard their own voices in the other ear as they tried to sing along. The second condition provided a visual cues in addition to the auditory set-up the subjects saw on a moving graph how their versions compared with the model's simultaneously with the subjects' singing it. Half the subjects practiced with the visual cue during the first part of the training, half during the second part, but subsequent staflstical tests showed no significant difference due to order. Like C. E. Seashore, Heller found the bimadal feedback superior to auditory alone for frequency matching and pitch adjustment.

Kuhn in 1967 did a plilot study for computer-assisted teaching of sightsinglng Intervals. In this case the computer Indlcated whether the sung pitches were correct. Students became more aware of subtle pitch differences and were able to improve their PR, to the criterion estabIIshed by the program. Although the results were considered tentative and the subjects were music majors, this seems another potentially effective method for giving immediate, mechanized feedback to inaccurafe singers as well. The fact that it can be done without any instructor present mey be important both for research and training that involve inaccurate singers, who often are embarrassed to sing in front of anyone (McNitt, 1971).

Training Inaccurate Singers. One of the more comprehensive studies prior to the 1960's was that of Wyatt, reported in 1945. After 
a thorough critical review of the earlier remedial work, she described her own study in which 16 university students, half of whom were music students, half non-music students. (mainly very inaccurate singers), received Individual training in PD and PR. After taking the Seashore PD test and Wyatt's own PD test, the subjects were glven 12 50-minute training periods in PD and PR, with emphasis on whlchever area was weaker. The PR training was only on a few trequencies: the standard $500 \mathrm{~Hz}$ and the whole and half tones above and below the standard. All subjects had the use of the Straboconn (described above, see Guerin) to check vocal precision and correct their voices if necessary. As is aimost always the case in the early research of this nature, the standard training procedure was varied if it didn't produce the intended results. The subjects were first fold to listen to the tone sounded 3 times on the oscillator, then to sing into the Stroboconn and try to correct their intonation. However, it they still couldn't match the tone, the experimenter tried a series of alternatives:

1) used a lower pitch standard, 2) asked the subject to sing along with the standard, 3) played the standard on the piano instead of the oscillator, 4) the experimenter sang the standard. Wyatt notes that the fourth varlation seemed to help as a last resort. This would be further support for Knock's idea (1922) that subjects were more easily able to match pitches of a voice In their own range than of a funing fork, and were even better at matching their own voices.

After training all subjects were retested at least twice, using the pretests as posttests. The scores on the second administration of the pretest were compared with scores on the secondposttest. Improvement for music and non-music students was highly significant at the 
18 and $2 \%$ levels of confidence respectively, on both tests. Wyatt also found significant transfer of PD improvement on two frequencies not practiced. It should be kept in mind though, that these other frequencles were an octave above and below the standard, and the results need not Imply transfer to lessobulously related frequencies.

Unfortunately no actual testing was done on PR since Wyatt was mainly interested in PD ability. However, the discussion of the training suggests that all the subjects learned to match the few pitches being used. This is another instance in which training in PR was used to augment direct training in PD. However, since no contral groups were included who did not have PR training, the effect of its Inclusion cannot be measured. In addition, since there was no control group which did not get visual teedback, its effectiveness in isolation cannot be measured.

Despite the evidence of the effectiveness of auxilliary visual teedback, few studies have been done to clearly establish its usefulness in remedial work with Inaccurate singers. A study which moved in this direction was done by Wells in 1965. A sample of high school students was assigned to one of three groups: A received 3 minutes of training dally for 20 days, using a 5 troboconn; $\underline{B}$ received the same amount of training, but using the plano; and $\underline{C}$ participated in normal voice class activity with no extra training. On a posttest of vocal pltch performance, group A made signiflcantly greater galns than $B$, and both $A$ and $B$ improved significantly more than C. Although only a minority of the subjects had large initial pitch deviations, these seamed to improve more than the others (Wells, 1965), which further supports the hypothesis that something about the visual aid is effective 
in training very inaccurate singers.

A much longer and more ambitious training program aimed specifically at the inaccurate singer was carried out by McNitt, reported in 1971. During the course of a summer term, 19 adult "uncertain singers" took between 9 and 16 hours to complete the extensive pre- and posttesting and the self-instructional program designed by MeNitt. This is one of the few studies reviewed in which all instructions were taped and training was identical in form for all subjects, although the design of the program allowed the subjects to repeat each part until correct to a criterion. Subjects spent two half-hour sessions weekly until they had completed the program. The training included listening to the tone and imagining it, singing with the model, and singing alone (stages which were adopted for the present experiment) on a series of tasks presumed to be in order of difficulty based on pilot work and previous research. All subjects used the Stroboconn for visual KR. Results on the Seashore PD test and MoNitt's own Vocal Pitch and Rhythmic Accuracy test showed no significant relatlonship between vocal pitch accuracy and either PD or tonal memory, in contrast to Bentley's findings. Thus once more the question is unenswered as to what klnd of relationships exist among the components of musical abllity. However, McNitt did find a statistically significant improvement in vocal pitch accuracy between the pre- and posttest, and this difference held up on the second posttest, given a week later. McNitt notes that all subjects learned to match the model and all but the two who scored lowest on the pretest were able to sing the test songs without the model affer training. As was found in most of the remedial studies, the largest improvement, though not the highest final scores, 
occurred in those subjects initially least accurate.

More information concerning just what role visual KR played might have been available if McNitt had used a control group who did not get the visual feedback but used the ldentical training program.

\section{Sumary}

Up to this polnt we have looked at the evidence that PD and PR are related, and that improvement in one usually correlates with improvement in the other even when only one of the two skills is explicitly practiced. In addition, we have noted that many remedial methods have been used with at least some success. However, most of the experimenters were primarily trying to help the singers improve and only secondarily trying to determine precisely what $k$ ind and quantity of treatments worked best under what conditions. Therefore the reader or potential teacher is left only with the general sense that individual differences must be considered, but not with clearcut guldelines as to the kinds of treatment that might work best with certain kinds of singers or singing problems.

Indeed, some treatments might be generally effective, at least as a flest step, and it is this connection that the present experiment was designed.

Earlier research and the experiences of the author in music feaching and pilot studies have shown that singers are often quite inhibited about singing, having so often been given negative feedback or been told to "just mouth the words" (MCNitt, 1971; Wyatt, 1945; Smlth, 1914; Whipple, 1903; Bentley, 1968; Rarm, 1947; Greenberg, 1970). In addition they are frequentiy doubtful that improvement is possible for 
them, are hesitant to embark on a lengthy training program that might lead to another failure. For these reasons a treatment was planned which would require no one but the subject to be present during the teaching or training, all of which would be very brief ( $1 \frac{1}{2}$ hours, all at one sitting) and would provide immediate, continuous and unambiguous knowledge of results visually, that is, through a sensory channel not likely to be associated with prior fallure at singing.

Previous studies have shown visual feedback to be an effective accessory cue in training psychomotor (Annett, 1959) as well as musical abilities (reviewed above). However, none of the studies of remedial training in pitch reproduction for inaccurate singers that was reviewed provided a design which adequately differentiated between the effect of Immediate visual treatment with practice and the effect of the identical practice alone, and then contrasted both of these conditions with a control group which got no practice at all. The present study attempted to do this. 
CMAPTER III

\section{EXPECTED RESULTS}

This study was designed to investigate whether Immediate, continwous visual feedback would be significantly better at helping the Inaccurate singer to Imitate Individual pitches than would the identicol tralning without the auxillary visual ald. A control group got nelther training nor visual feedback so that by comparing all fbree groups it could be determined whether elther experimental treatment had a significant effect.

Based on the literature reviewed and on the pllot studies, it was expected that even a brief training session allowing only nine conseculive trials per note would have the effect of improving an inaccurate singer's ablility to correctly imitate the eight single pltches in the $\mathrm{C}$ major scale. Thus the two experimental groups should have hlgher scores than the control group on the posttest. Because of the brevity, however, it was thought that the Improvements might not be large or consistent enough to be refiected significantiy in the posttest. Therefore a close comparison of the responses during training of the two experlmental groups was planned, to provide another measure of the sub.jects' improvement and to ascertain whether those who received the auxiliary feedback scored higher than those who got no visual cues.

In keeping with the earlier findings and observations made during the pilat studies, it was expected that many of the subjects would have 
low voices and thus would experience more difficulty on the higher notes. Low-voiced subjects were expected to have significantly lower scores on the posttest than normal-voiced subjects would have.

The earlier research also suggested that subjects would tend to have normal hearing. No correlation was expected, therefore, between performances on the pitch matching tests and hearing acuity.

Although the major hypotheses were related to the results of the formal experiment, several assumptions were Implicit in the research design and comments on these were soliclted during the informal interview that followed the posttest. It was assumed that all subjects would appreciate and benefit from having no one in the room, having a vocal model approximately in their own range and having a chance to pace themselves. In addition, it was assumed that the subjects in the two experimental groups would appreciate being able to sing along with the model, repeat each note nine times consecutively and compare thatr own recorded volces with those of the models. The immediate knowledge of results provided by the visual feedback was expected to reduce the uncertointy about accuracy. Subjects would then be less likely to underestimate their actual ablility, be more aware of incremental improvement, and leave with a more positive opinion of their pitch matching ability than they had initlally. Also, since the feedback would immediately indicate the direction of error, it was expected to reduce the interference with the task that might otherwise result from the frustration of knowing one was off but not knowing whether to sing higher or lower. Because subjects in the control group were given virtually no time to practice and no indication of accuracy, it was expected that they would leave the experiment least encouraged and 
with the least accurate sense of their pitch matching ability. 
CHAFTER IV

\author{
DESIGN OF THE EXPERIMENT \\ 1. SUBJECTS AND EQUIPMENT
}

\title{
subjects
}

Thirty subjects were solicited from classes at Portland State University durlng the first few weeks of summer session, 1976. In addition, subjects were sought through an advertisement in the Vanguard, The school paper. Subjects were told only that the investigator was interested in volunteers who felt or had been told that they were very uncertain or I naccurate singers, that is, people who had considerable difficulty in carrying a tune or even imitating individual pitches.

\section{Equipment}

A Stroboconn, Model $6 T-2$ was used for providing visual feedback. It gives immediate indlcation of whlch pitch is being sung and whether that pitch is accurate, sharp or flat, and to what degree. A photograph of this device appears in Appendix F. A Language Master tape recorder was used for listening to and recording volces during the training sesslons and posttest. With it the subjects can repeatedly IIsten and record, using $4^{\prime \prime}$ by $8^{\prime \prime}$ cards with strips of recording tape across them. A single pitch was pre-recorded on the left half of each card by a model of the same sex as the subject. An Ampex monophonic tape recorder was used to record both the pretaped stimull and the subjects' nesponses 
during ail tests and training trials.

\section{METHODOLOGY}

\section{Hearing Tests}

Every effort was made to schedule all volunteers for a ten-minute audiological examination, which was administered in the Speech and Hearing Sciences Department by an audiologist. Hearing in each ear was Fested at the following frequencles (in Hertz): 250, 500, 1000, 2000, 4000. These fall into the speech frequency range.

\section{Assignment to Groups}

At the time of volunteering each subject signed up for a single hour-and-a-half session, at a time convenient for him/her. Each volunteer had the same probability of receiving any one of the three traatments, that is, each was randomly assigned to a group based on the order in which s/he arrlved to do the actual experiment.

\section{Initial Assessment of Ability}

A measure (referred to as "prescore") was taken at the beginning of each individual session to provide an initial assessment of the sutject's ability to match pitches. These results were used as a covariate in some of the subsequent statistical tests to assure that the three treatments had siml lar proportions of very inaccurate or hardly at all inaccurate singers. This measure consisted of 40 pitches: the eight notes of the $C$ major scale sung five times in random order by a model of the same sex as the subject. Taped Instructions told the subject to try to match each pitch vocally. Both the pretaped model's pitches and the subjects' responses were recorded on the Ampex 
tape recorder for later scoring.

Instructions for Using Equipment and Doing Procedure. Each

subject was given taped instructions describing the equipment and procedure that was relevant for his group. He was also provided with an outline of these instructions typed on cards and o chart for checking off each trial as it was done. Refer to Appendix E for coples of all instructions and charts. All subjects received ten cards for use in the Language Master tape recorder. The first two cards were for practice In the use of the equipment. During this initial five to ten minute familiarization period subjects heard and sang pitches that did not appear on any tests or in the maln part of the practice session. The author or her asslstant was avallable if needed to answer questions, but was not present during any testing or practice trials. Each of the main cards had recorded on if one of the eight notes in the $\mathrm{C}$ major scale, sung by a model of the same sex as the subject. The pltches were arranged arbitrarily to prevent any improvement as an artifact of the relative ease of singing notes stepwise, as they come in the scale.

\section{Ireatment Groups}

There were three treatment groups: two experimental groups and one control group. Experimental group I (Non-visual) was given tralning with auditory feedback; that is, the oppostunity to compare their own taped voices with that of the model. Experimental group II (Visual) was given the identical training but with additional visual feedback presented simultaneously. The control group was given no training on the pitches of the $C$ major scale and neither auxiliary audltory nor 
visual feedback.

Experimental Session. Each subject in the Visual and Non-visual groups used the following procedure which s/he had become familiar with as $s$ he learned to use the equipment:

$$
\begin{aligned}
& \text { Listen to the model............ Imagine the pitch } \\
& \text { Listen..................... sing along }(2 \text { times }) \\
& \text { Listen.................... imitate }(5, i m e s) \\
& \text { Listen. .................... record, then listen and compare } \\
& \text { recording of own volce with that } \\
& \text { of model }(2+1 \text { mes })
\end{aligned}
$$

Each subject in the two experimental groups thus heard and sang each pltch nlne times and had two chances to hear her/his own voice on tape and compare $1+$ with the model before trying to imitate again. If the subject was in the visual group (11) then s/he was able to get Immediate, continuous visual feedback from the Stroboconn throughout the whole sesslon, including the training period and posttest.

\section{Posttest}

The posttest included the tollowing steps for each of the eight pitches of the $G$ major scale:

$$
\text { Listen.....................Record }
$$$$
\text { Listen............................... over the first recording }
$$
The two experimental groups took the posttest immedlately following their nine practice trials on each of the eight notes. The control group took it immediately after becoming famillar with the equipment and being instructed in the posttest procedure. In contrast with the experimental groups, the controls had no practlce trials on the pitches 
of the $\mathrm{C}$ major scale. Thus on the posttest each subject had two trials for Imitating each of the eight notes, but the feedback during these trials varied with the group and was comparable to that used during the training session; that is, the Non-visual group got no auxiliary visual feedback, the Visual group got visual feedback and the control group got no visual feedback.

Scoring. All responses on all measures and on the pracfice trials for the two experimental groups were taped along with the pre-recorded pitches of the models. Two judges, the author and her assistant, used a 5-point scale for the subsequent scoring of each response of the initial assessment measure (prescore), the training procedure and the posttest for each subjact in the Visual and Non-visual groups and for scoring the prescore and posttest for those in the Control group. The scale was as follows:

0 : more than a whole step off

1 i a whole step off

2 ; a half step otf

2.5 : a quarter step off or less, but not quite on $3=$ on pitch

During the scoring it was found that several subjects were approximating the correct pitch except for being an octave above or below the model. This was noted and additional "octave-off" scores kept where relevant. Pearson's correlation coefficients were compisted to assess the reliabilities of judgement between scorers, using both the regular and octave-off scores for both judges. The complete scoring plan appears as Table 1 below, in the Results chapter. 
Interview

Immediately following the postlest the subjects were interviewed using a semi-structured questionnaire. The suggested questions for the interviewer to use appear in Appendix D. The purpose was to elicit comments on the experimental procedure and the experience, to inquire about the subjects' early muslcal experionces, how and when they became aware they had trouble carrying a tune and their families' musical abilities and attitudes towards music. Because the interview was not rigorousiy formal or standardized and because it was suspected that different subjects would tend to elaborate certain areas and respond laconically in others, only limited statistical correlations between the results and the subjects' scores were plannerl, 


\section{CHAPTER V}

\section{RESULTS}

\section{COMPARISON OF GROUPS}

\section{scoring Plan}

Each of the two judges used the 5-point scale to score all subjects' taped responses on two measures, a prelliminary ablitity measure (prescore) and a posttest, and to score the two experimental groups (Non-visual and Visual) on the training procedure as well. These three measures (prescore, tralning procedure and postlest) and the 5-point scale are fully described In the Methods section.

Because it was found that seven of the 30 subjects tended to sing close to the pitch which was an octave above or below the model's, additional octave-oft scores were recorded for them, applying the same scale to responses within a whole step of those octave-off pitches. The entire scoring plan, Including group means and standord deviations, appears In Tabie 1 below.

\section{Reliabilities}

Pearson correlation coefficients were computed on these variables to assess the level of reliabilities of judgement between the two scorers. Results of this analysis showed that the range of reliabilities was from $r=.98$ to $r=.996$, with an average of $r=.9914$. Because of the high level of reliability, the two judges' scores were averaged and the averages used in all subsequent analyses. 
TABLE |

\section{SCORING PLAN WITH GROUP MEANS \\ AND STANDARD DEVIATIONS}

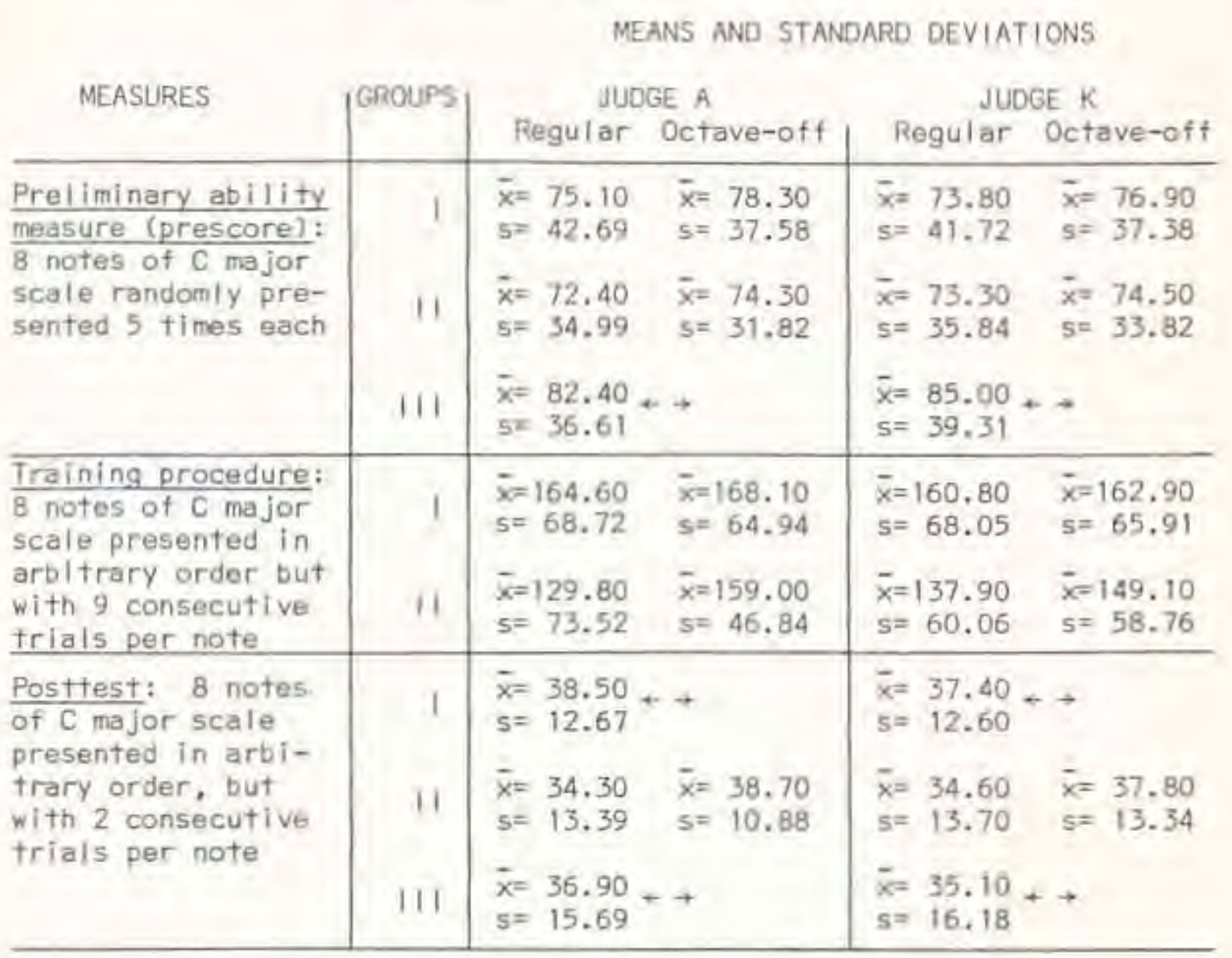

When the octave-oft scores nere substituted for the regular scores in the seven relevant cases, the changes in the group means were insufticient to warrant doing separate statistical tests. Thus for ail other tests only the regular scores averaged between the two Judges were used as the dependent vartables or Eovariate (see Appendix A: Averaged scores on all measurest.

Comparisons of Treatments. Despite rendom assignment to conditions, group averages on the prescore were different, as shown in Table I above. Since fairly high Pearson's correlation coefficients were found between 
the prescore and the posttest $(r=.68$ to $r=.97, w i t h$ an average of $r=.81$ ) and between the prescore and the training procedure score $(r=.80$ to $r=.86 \mathrm{with}$ an average of $r=.83)$ analyses of covariance were used to test for the main effect of training and the specific gt fect of visual feedback during training. Since no way was known to pertorm an analysis of covariance with repeated measures and because the adjustment for the covarlate did not change the results significantly on the preceding two analyses (see Tables 11 and 111 below), an analysis of varlance was used to compare the subjects' performances on high and low notes.

The purpose of the first analysis of covariance was to equate the three groups statistically according to the prescores and then compare their pretest scores. Desplte this adjustment the results showed there were no significant differences among the groups $\left(F_{2,26}=.865\right)$ (see Table (1). This means that the training session had no signiticant effect, whether or not it included visual feedback. Results of the second andysis of covariance, comparing the two experimental groups on thalr adjusted training procedure scores showed that the condition (1:Non-visual, 11:visual) under which the subjects tried to imitate the pitches did not produce signiticant difterences in the overall traininge procedure scores $\left(F_{1,17}=1.587\right)$ (see Table 111 ). The slight trend that did appear was the opposite of that expected: a comparison of the adjusted means showed that the Non-visual group mean of 161.57 was higher than the visual group mean of 140.83 . 
TABLE II

NON-VISUAL VS. VISUAL VS. CONTROL CONDITIONS: COMPARISON OF ANOVA AND ANCOVA FOR POSTTEST

\begin{tabular}{|c|c|c|c|c|c|}
\hline TEST & SOURCE & SS & DF & MS & F \\
\hline \multirow[t]{2}{*}{ ANOVA } & Condition & $\begin{array}{c}\text { SSy Between }= \\
61.517\end{array}$ & $J-1=2$ & $\begin{array}{c}\text { MSy Between = } \\
30.759\end{array}$ & \multirow{2}{*}{$\begin{array}{l}F_{2,27} \\
=.115 \\
n .5 .\end{array}$} \\
\hline & Error & $\begin{array}{c}\text { SSy within }= \\
5356.95\end{array}$ & $N-J=27$ & $\begin{array}{c}\text { MSy With/n }= \\
198.405\end{array}$ & \\
\hline \multirow[t]{2}{*}{ ANCOVA } & Condition & $\begin{array}{c}\text { SSy' Between }= \\
109.056\end{array}$ & $J-1=2$ & $\begin{array}{c}\text { MSy' Between }= \\
54.528\end{array}$ & \multirow{2}{*}{$\begin{array}{l}F_{2,26} \\
=.865 \\
\text { n.s. }\end{array}$} \\
\hline & & $\begin{array}{c}\text { SSy' within }= \\
1638.172\end{array}$ & $\begin{aligned} N-J-1 & \\
& =26\end{aligned}$ & $\begin{array}{c}\text { MSy' Within }= \\
63.007\end{array}$ & \\
\hline
\end{tabular}

TABLE 111

NON-VISUAL VS. VISUAL CONDITIONS:

COMPARISON OF ANOVA AND ANCOVA.

FOR TRAINING PROCEDURE

\begin{tabular}{|c|c|c|c|c|c|}
\hline TEST & SOURCE & SS & DF & MS & F \\
\hline \multirow[t]{2}{*}{ ANOVA } & Condition & $\begin{array}{c}\text { SSy Between = } \\
2493.79\end{array}$ & $J-1=1$ & $\begin{array}{c}\text { MSy Between = } \\
2493.79\end{array}$ & \multirow{2}{*}{$\begin{array}{l}F_{1,18} \\
=.597 \\
\text { n.s. }\end{array}$} \\
\hline & Error & $\begin{array}{l}\text { SSy within }= \\
25135.75\end{array}$ & $N-J=18$ & $\begin{array}{c}\text { MSy within }= \\
4174.208\end{array}$ & \\
\hline \multirow[t]{2}{*}{ ANCOVA } & $\begin{array}{l}\text { Condition } \\
\text { (adjusted } \\
\text { effects) }\end{array}$ & $\begin{array}{c}\text { SSy' Between = } \\
1953.77\end{array}$ & $J-1=1$ & $\begin{array}{c}\text { MSY' Between }= \\
1953.77\end{array}$ & \multirow{2}{*}{$\begin{array}{l}F_{1,17} \\
=1.587 \\
\text { n.5. } \\
\text { P }<.25\end{array}$} \\
\hline & Error & $\begin{array}{l}\text { SSy' Within }= \\
20919.13\end{array}$ & $\begin{aligned} N-d-1 & =17 \\
& =17\end{aligned}$ & $\begin{array}{c}\text { MSy' Within }= \\
1230.537\end{array}$ & \\
\hline
\end{tabular}




\section{PHYSIOLOGICAL TRAITS AND PERFOFMANCES}

\section{Voice Range and Performance}

An analysis of variance with repeated masures was performed to compare the two experimental groups on the factor of notes, using as the dependent variable the scores on the train/ng procedure and the posttest for four of the eight notes: the two lowest notes $(C, D)$ comprised the "low" level of the Notes factor; the two highest notes $(B, C)$ comprised the "high" level. The results of this analysis of variance showed that the overall levels of the two experimental groups were not significantly different $\left(F_{1,18}=.0303\right)$. The subjects' performances were not significsntly different on high notes and low notes $\left\langle F_{1,18}=3.8356, p<.10\right\rangle$, although there was a trend for performances 7o be better on the low notes. The mean on low notes, averaged over the two experimental groups was 186.065, while the averaged mean on the high notes was 169.83 . However, because the notes of the scale were presented in a fixed arbitrary order, not randomized for each subject, any comparison made between high and low notes is confounded with the variable of position of notes in the series. This should be examined in further studies as a possible source of error.

Low Voices. During the scoring of responses both Judges observed that nine of the 30 subjects had especially low voices. A Mann-whitney U test showed that the scores of those subjects with low volces were significantly lower on the posttest than were the scores of subjects with normel voices $(z=3.33, p<.0005)$. An unexpected finding (using The $z$-test of difference between two proportions) was the non-significant difference between the proportions of low and normal voiced subjects 
who ald better on low than on high notes $(z=-1.87, p<.06)$. Low volced subjects' performances did differ significantly on low and high notes, using a one-tailed test, but contrary to expectations, they tended to do better on high notes $(z=1.954, p<.05)$.

\section{Hearing Tests}

Audiological examinations were administered to all participants in the study except those four who were unable to make any of the aval lable appointment times due to full-time Job commitments. All of the 26 volunteers who were tested showed hearing to be within the normal range, which is $\pm 10 \mathrm{~dB}$ of audiometric 0 for the speech frequencles (in Hertzl $=250,500,1000,2000,4000$. The Spearman rank correlation coefflclent was computed, using as variables the audiological results for subjects' right ear (which was assumed the more appropriate ear in regard to the digital, or left-brained, nature of the experimental task) and results on the prescores. A very low correlation was found $\left(r_{5}=\right.$ .108). It is interesting to note that while some of those subjects with the highest scores had exceptionally good hearing, several with the lowest scores in each group also had quite good hearing and several subjects with the worst hearing had moderate to very high scores, Ranks on audiograms and prescores appear in Appendix G.

\section{INTERVIEWS}

Twenty-elght subjects were interviewed immediately following the posttest. Their responses varied considerably in detafl for both sollelted and unsolicited informatlon. Because the resulting data were based on varying numbers of responses per question, few quantitative 
analyses were attempted and most of the comments and interpretations should therefore be considered suggestive, not conclusive. Throughout the following discussion the proportions of those responding in a particular direction to a given question or volunteering unsoliclted information appear in parentheses.

\section{Comments on Design}

Subjects considered the following aspects of the experimental methodology to have been holpful:

1) Instructions were clear, though complex at times (20 of 25).

2) No one was present in the room during any part of testing or practice $(17$ of 21$)$.

3) The visual cueing device gave immediate information on the tegree of accuracy or direction of error ( 9 of 9 , Vis. group).

4) There was an opportunity to compare one's own vaice with that of the model (7 of 9 , Non-vis. group).

5) There was an opportunity to have many trials on each note and to pace oneselt individually (18 of 23$)$.

Some subjects expressed discomfort or annoyance at having to master the complex procedure involving so much manipulation of mechanical devices ( 5 of 21 ), but several of these felt nonetheless that the devices had been helpful ( 3 of the 5).

\section{Opinion of Pitch Matching Ability}

An examination of the responses to the questions, "How did you expect to do on this task before you started?", "How do you think you actually did?", and "How dld this make you feel?" suggested several trends. Subjects in all three groups tended to improve their opinion 
of accuracy regarding their pitch matching ability, apparently just from the process of participating in the experiment, and the proportion was significant, using a one-tailed test $(z=1.74, p<.05)$. There was some varlation among groups: the visual group seemed to differ significantly from the controls, using a one-talled test $(z=1.82, p<, 05)$, but not from the Non-visual group $(z=1,28)$ (VIsual: elght of nine; Non-visual: five of eight: Control: five of ten).

\section{Early Musical Experiences}

The early musical experiences reported here parallel those reported In the Iiterature (Reynolds, 1960; Rainbow, 1963; Updegraft, 1938; Shuter, 1968). Subjects tended to find out that they had trouble carrying a tune in grade school (13 of 24 ) or Junior high ( 8 of 24 ), usually In a muslc class or chorus. Often this became a source of embarrassment and frustration, and for some led to social isolation or discomfort, because their immediate family or peers were so regularly involvad in singing activitles. Many struggled with instruments as children (20 of 28) with varyling amounts of encouragement, but very few (2) continued more than three years. Subjects pointed to inadequate teachers, trustration at their slow progress, lack of sufficient encouragement, or the intervention of other more satistying interests, as explanations for quitting. Despite their lack of success, most of the subjects studied enjoyed music as chlldren (17 of 19) and have continued to do so $(20$ of 21$)$.

\section{Present Attitudes towards Singing}

Somewhat more than a third (9) of those interviewed voluntarily mentioned that they still love to sing and do so alone or with the radio. 
A few said they've begun to sing with others. Some continue to feel frustrated or unhappy about not being able to sing easlly and well ( 6 of 8 ), some have tried to improve ( 8 of 16 ), mostly with the help of friends. Others report that they are resigned to their condition and have found other outlets for their musical, creative or vocal needs (2). Although the question was not specifically asked, 8 expressed strong interest in improving their voices, especially if they could have access to a self-instructional method. 
CHAPTER VI

\section{DISCUSSION}

\section{COMPARISON OF GROUPS}

\section{Comparisons of Treatments.}

Results of the formal experiment and of the informal Interview suggest that many people who feel they are very inaccurate singers and who indeed may have a great deal of trouble carrying a tune often nonetheless are able to match individual pitches, especially in the lower part of their range. Although this skill may not be improved significantly with only a short-term structured practice session lasting no more than one hour, the experience does have a strong positive impact on the subject's opinion regarding pitch matching ablitity.

In the present experiment the main results did not come out in the expected direction: statistical tests showed the groups not to be significantly different in performance, as measured by scores on the training procedure and posttest. This may be a reflection of the sample who volunteered or the brevity of the training, which will be discissed below.

Initial Pitch Matching Ability

All volunteers who claimed they had frouble carrying a tune were accepted as subjects and then randonly assigned to groups. The preliminary assessment measure (prescore) was then administered immediately 
prior to the start of the training sor posttest, In the case of the Contral group). This aspect of the design prevented the author from rejecting as inappropriate those subjects who were able to score very high on the prescore. Although an analysis of covariance was performed on the data to adjust for the subjects' varying abilitles at the start, results may have been different if all subjects had had severe difficulty in matching pitches. In the present sample there was a large proportion of subjects $(73 \%)$ who were al ready able to match Individual pitches with $50 \%$ accuracy at the start, and $56 \%$ who were able to accurately match over $75 \%$ of the 40 random pitches which made up the prescore. In the posttest the task was altered to allow subjects to pace themselves and to have two trials per note, but no substantial practice. The results of this test for the Control group showed that 70 f of the so-called inaccurate singers in that group were able to match single pitches with even greater accuracy [>91\%] than they could on the prellm. This suggests that the tasks were too easy or the subjects not as Inaccurate as they had assumed, or both.

\section{PHYSIOLOGICAL TRAITS AND PERFORMANCES}

Low Volices

Although there was only a slight trend $(p<.10)$ for performances to be better on low notes than on high ones, this result was noted in the Results chapter because of the literature on the development of chlldren's singing ranges and because of the slgniflcantly lower scores on the postfest recelved by low-yoiced subjects in the sample $(z=3.33)$. The literature reviewed suggests the possibility that these low-voiced subjects experienced special difficulty both in grammar school and in 
the present experiment because their voices are below the normal range. Farnsworth (1958) and Nye (1962) reported that songs for use in early elementary grades are often written in a range difficult for many chlidren, especially those with low volces. Thus the latter are at a disadvantage from the start, and without approprlate extra help they are likely to feel discouraged and ambarrassed. This often leads to withdrawal from the experience and continued vacal difficulty CMcNitt, 1971).

It was not unexpected that some of the subjects in thls sample would turn out to have low voices. Among the nine who were observed to be straining considerably on the higher notes, five were women who seemed to sing more easily, if not more accurately, In the normal male range and lower part of the female range. Although It would seem likely that the presence of these low-volced subjects may have been a factor in establishing the sllght trend towards better performances on the low notes that was found in the repeated moasures of analys Is of varlance, this was not the case. Despite the straln, low-voiced subjects' performances on the posttest were significantly better on the high notes, with a one-talled test $(z=1.954, p<.05)$. Their overall performances were signiflcantly lower than normal-volced subjects $(z=3.33)$. This result seems to contradict Joyner's (1969) finding that many so-colled "nonotones" could sing accurately at lower plfches though they were inaccurate at higher pltches. However, in the present study, the confounding of high and low pitches with position must again be noted as a possible source of error.

Octave-off Responses. Of the seven subjects whose responses gradually approximated the correct pitch (e.g. C, G) but an octave above 
or below the model's, five were in the Visual group. Although this proportion did not reach significance on a z-test, the fact that half of the Visual group tended to sing an octave off underscores the need for future investigators who use the Stroboconn to Include Instructions on how to discriminate octaves visually. Lacking this information, the VIsual group very I Ikely assumed their octave-off responses were correct, because they did cause the discs in the stroboconn windows to appear to slow down or stop - the criterion for accuracy.

Hearing Tests

The finding that there was a very low correlation between results of the audiological examinations and accurate pitch matching is in accord with results reported by Culpepper (1961), Bentley (1968) and Farnsworth (1938). They also nofed considerable varlation in hearing acuity among normal singers as well as among inaccurate singers, as was reviewed in Chapter 11 above.

\section{INTERVIEWS}

\section{Comments on Design}

Subjects' responses during the interview showed that they appreclated some aspects of the design even if these were not enough to significantly improve their scores. Subjects in the experimental groups considered one or more of the following to have been helpful: selfpacling, privacy, multiple trials per ltem, clear instructions, and opportunity to compare thelr voices with the model's. In addition, subjects in the Visual group included as helpful the Immediate feedback an accuracy and degree and direction of error. 
Opinion of Pitch Matching Ability

One of the design considerations of this experiment was to show Inaccurate singers as quickly as posslble that they had underestimated their pitch matching ablility. It was hoped that thelr improved opinion regarding this skill would so stimulate and encourage them that they might be able to break the negative cycle of bad early experiences discouragement, low opinion of slnging ability, reluctance to risk trying again. With a more suocessful experience behind them it was hoped that they would be more willing to invest the time and energy in a longer, more complex vocal training program, should one become available.

It was expected that the Stroboconn would most effectively and accurately help subjects raise their opinions since it provided them with immedlate, continuous information about degree of error. The responses on the informal interview showed that subjects' opinion of their pitch matching ability rose and tended to become more accurate than it had been initially, a result which was significant with a one-talled fest, even though their performances did not improve significantly. However, the Stroboconn did not have a significantly different effect. Apparentiy not only the subjects in the visual group were positively aftected by their trief experience. The proportions of those subjects who left the experiment with a better and more accurate opinlon of their ability than they had initlally were significantly different between the Visual and Control groups (with a one-tailed test), but not significantly different between the two experimental groups.

Although three of the eight who volunteered the intormation that they would be interested in improving their voices were from the visual 
group, four of the others were in the control group and thus had had no chance to practice. It would seem that the experiment provided an opportunity to check out very quickly one's long-held negative assumptions about a particular musical skill in a relatively non-threatening environment: no one else present, no expectations by others that one should do well or badly. 
CHAPTER VII

CONCLUSIONS AND RECOMMENDATIONS

1. CONCLUSIONS

Contrary to expectations, at least in the course of this very brief experiment, the visial feedback was not a significant aid. In fact, since subjects had not been taught to discriminate octaves yisually and were not necessarlily able to do so aurally, several began to approxImate the pitch an octave off from the model's, incorrectiy interpreting the stroboconn.

Although those given visual feedback did not score higher as a group, they tended to comment enthusiastically about the method. Several inquired about the possibility of making individual use of the stroboconn after the experiment. The Hawthorne effect cannot be ruled out as a factor here. Indeed, subjects in the Visual group had the most equipment to master and thus the longest instructions and session. However, subjects in all groups tended to improve their opinion about their pitch matching ablility, reaching their more accurate assessment opparentiy simply as a result of participating in the experiment. In the Itterature reviewed the Stroboconn was found to be an effective tool for improving pitch matching of Inaccurate singers. It should be noted, however, that none of the prevlous studies made use of so brief a practice period as did the present experiment. None of those earlier studies compared a group who had received visual feedback with 
a group who had had the identical practice without the feedback, so it was never clear whether the training procedure or the fact that visual feedback was given produced the signiflcant effect of treatment. Given the non-significant results of the present experlment, future studies might Include a whole series of practice sessions, to try to increase both the overalt practice effect and the difference between experimental groups. It would be interesting to see whether the initial sllight lead taken by the Non-visual group in this experiment would be malntained or would diminish over tlme.

The conflict between the need to account for indlvidual differences in subjects and the requirements of solid scientific research remains unresolved. As was noted in the review of the 1iterature, individuals seems to respond best to custom-designed tralning programs, but these make tight comparisons of effect of differant treatments virtually impossible. As a compromise, one might set up carefully designed selfInstructional programs which enable each individual to work at his or her own pace and to emphasize those aspects which are most troublesome to that person. As in the present experiment, for comparative purposes one group could be given visual feedback throughout and the other glven the identical practice but without the feedback.

\section{RECOMMENDAT IONS FOR FUTURE RESEARCH}

1. A pretest should be given to all volunteers before assigning Them to groups to enable the experimenter to analyze the results and divide the subjects into matching groups. Those who score above a preestablished criterion would not be included in the sample. A second administration of the pretest should be given and these scores compared 
with posttest scores to minimize error due to regression toward the mean.

2. Those aspects of the design should be kept whlch seemed to be helpful to the subject for reducing stress, for providing feedback, encouragement and a sense that the task is feasible. These include the following: self-pacing, privacy, multiple trials per tiem, clear insfructions, Immediate feedback on accuracy and degree and difection of error, opportunity to compare one's recorded volce with that of the model.

3. As in the prosent study two experimental groups should be used. Each should be given identical training except for the additional sisual feedback which should be provided for only one group.

4. To reduce the potential error due to the Hawthorne effect, attempts should be made to provide the Non-visual group with a different kind of equally novel and complex treatment, either in the form of equipment or attention.

5. Although more complex In design, the tralning sessions should gradually increase the number of notes in a row to be matched. This would provide a better basis for assessing progress with 1naccurate singers and would provide more approprlate trainlng as mell. Ideally the models for imitation would eventually approximate actual melodies in length and form. While outside the scope of a master's thesis in psychology, a similar procedure has been atformted with considerable success (MeNiti, 1971).

5. At least three practice sessions and preferably several weeks of tralning should be scheduled. This would accomodate the more complex deslgn proposed in 5. above and be more likely to provide sufficient time for subjects to make significant and, one hopes, long Iasting gains. 
7. There should be a plan for gradually fading the feedback or "weaning" the subjects who are using visual feedback to the point where they have only auditory feedback. This would help eliminate the problem of overdependence on the visual aid and yet not lose the benefits gained by the initial (or substitutive) visual cueing. The author is aware of no attempt to do this reported in the literature.

8. Subjects who are given visual feedback from the Stroboconn should be trained to discriminate among octaves to eliminate that source ot error.

9. The taped model should be identical in range to the subject, especially at first. The range could then be extended as the subject geined accuracy within the inftial range.

10. A carefully planned questionnaire should be given to all particlpants, who should be encouraged to respond to every item, thus facilitating quantitative as well as qualitative analyses of the data.

11. Pre- and posttests shoula be identical to provide an adequate measure of improvement in both experimental and control groups.

12. Careful attention should be paid to the possible effect on performance of order of presentation of stimuli. Appropriate counterbalancing should be included in the design. 


\section{A. SELECTED BIBLIOGRAPHY}

Abercromble, D. Elements of general phonetics. Chicago: Aldine Fublishing Co., 1967.

Annett, I. Learning a pressure under conditians of immediate and delayed knowledge of results. Quarterly Journa! of Experimental Psychology, 1959, 11, 3-15.

Bentley, A. "Monotones": A comparlson with "normal" singers in terms of Incidence and musical abilities. London: Novello $8 \mathrm{Co} .$, Ltd., 1968.

Bernsteln, 1. H. Gan we see and trear at the sane time? Acta Psychologie, $1970, \underline{33}, 21-35$.

Bridger, W. H. Sensory hablfuetion and diserimination in the human neonate. American Journal of Psychistry, 1961, 117, 991-996.

Cameron, E. H. Effects of practice in the discriminatlon and singing of tones. Psychologlcal Monographs, 1917, 23, nr.100, 159-180.

Capurso, A. A. The effect of an associative technique in teaching pitch and Interval discrimination. Journal of Applied Psycholony. $1934,18,811-818$.

Connette, E. The effect of practice with knowledge of results upon pitch discrimination. Journal of Etucational Psychology, 1941, 32. 523-532.

Culpepper, L. R. A study of the hearing impaiments in defective singers. Unpublished doctoral dissertation, George Peabody College for Teachers, 1961.

Eicstrom, R. C. Comparison of the male voice before, during and atter mutation. Unpublished doctoral dissertation, University of Southern Callfornia, 1959.

Farnsworth, P. R. Auditory acuity and musical ablifity in the first four grades. Journal of Psychology, 1938, 6, 95-98.

Forniswarth, P. R. The social psychology of music. New York: Hott, Rinehart and Winston, 1958.

Greenberg, M. Muslcal achievenent and the self-concept. Journal of Pesearch In Music Education, 1970, 18, (1), 57-64, 
Guerin, C. F. The effect of feedback modes on the external intonation of selected grade school instrumental students. Unpublished doctoral dissertation, Columbia University, 1972.

Heller, J. J. Electronic graphs of musical performance: A pilot study in perception and learning. Journal of Research in Music Education, 1969, 17, (2), 202-216.

Jersfld, A. T. and Bienstock, S. F. A study of the development of chilidren's ability to sing. Journal of Educetional Psychology. $1934,25,481-503$.

Joyner, D. R. The nonotone problem. Journal of Research In Music Education, 1969, 17, (1), 115-125.

Ki rkpatrick, W. C. Relationships between the singing ability of prekindergarten children and their muslcal environment. Unpubitished doctoral dissertation, University of Southern Callfornia, 1962.

Knock, C. J. Visual trainlng of the pltch of the voice. Psychological Monographs, 1922, 31, whole nr. 140, 102-127.

Kuhn, W. E. and Allyin, R. Computer-assisted teaching: a new approach to research in music. Bulletin of the Counclil of Research in Music Education, 1967, 11, 1-13.

Leantiev, A. N. The nature and formation of human psychic properties. in B. Simon (Ed.), Psychology in the Sovist Unjon. London: Rout ledge skegan Paul, 1957, p.226-232.

Loontlev, A. N. On the blological and soclal aspects of human development: the training of auditory ability. In M. Cole \& 1. Maltzman (Eds.), A handbook of contemporary soviet psychology, New York: Baslc Books, Inc., 1969, p.423-440.

Malnwarlng, J, KInaesthetic factors in the recall of musical experiance. British Journal of Psychology, 1933, 23, 284-307.

MeNitt, H. F. A self-instructional program for adult uncertain singers. Unpublished doctoral dissertation, Pennsylvania State University, 1971.

Moss, W. J., Jr. A study in the use of bone conduction hearing as an aid to improving out of tune singers. Unpublished doctoral dissertation, Unlversity of Miami, 1973.

Nye, R. and V., Aubln, N. and Kyme, G, Singing with children, Belmont, CA. : Wadsworth Publishing Co., 1962.

Pedersen, 0. M. and Pedersen, N. D. The relationshlp between pitch recognition and vocal pitch production in 6 th grade students. Journal of Research in Music Education, 1970, 18, (3), 165-272. 
Fowell, 1. C. A study of the relatlonship of singing accuracy to the pltch matching abilities of 81 subjects. Unpublished doctoral dissertation, Unlversity of Oklahoma, 1969.

Rainbow, E. L. A pilot study to investigate the constructs of musical aptifude. Journal of Research in Music Education, 1965, 13, (1), $3-14$.

Rarm, K. M. Personality maladjustment among monotones. Smith College Studies in Soclol Work, 1947, 17, 264-284.

Reynolds, G. E. Enxironmental sources of musical awakening in preschool children. Unpublished doctoral dissertation, University of 111 inols, 1960.

Roberts, E. and Davies, A. D. M. Poor pitch singing: response of monotone singers to a program of remedial training. Journal of Research in Music Education, 1975, 23, (4), 227-239.

Seashore, C. E. and Jenner, E. A. Training the voice by the eye in singing. Journal of Educational Psychology, 1910, 1, 311-320.

Seashore, C. E. The psychology of music. New York: MoGraw H111, 1938,

Seashore, H. and Bavelas, A. The functioning of knowledge of results in Thorndike's I Ine-drawing experiment. Psychological Review, $1941,48,155-164$.

Seashore, R. H. Improvability of pitch discrimination. Psychological Bulletin, 1935, 32, 546.

Seif. T. F. and Howard, J. H., Jr. Stimulus competiblility effects of an accessory Visual stimulus on auditory sensitivity. Perception and Psycophysics, 1975, 17, (5), 504-510.

Shuter, R. The psychalogy of musical ablilty. London: Methuen, 1968.

Siegel, 5. Nonparametric statistics for the bohavioral sciences. New York: McGraw-Hill Book Co., Inc., 1956.

Smith, F. D. The effect of training in pltch discrimination. Psychological Monographs, 1914, 17, (3) Whole nr. 69, 67-103.

Swanson, F. J. Voice mutation in the adelescent male: an experiment in guiding the voice development of adolescent boys in general music classes. Unpublished doctoral dissertation, University of Wisconsin, 1959.

Thorndike, E. L. Fundamentals of learning. New York: Teachers College, Columbia U., 1932. 
Updegraff, R., Heiliger, L. and Learned, L. The effect of training upon the singingability and musical interest of three-, four-, and five-year-old children. University of lowa Studies in Child Welfare, $1938,14,83-121$.

Vernon, P. E. Auditory perception: I The gestalt approach. British Journal of Psychology, $1934,25,(2), 123-139$.

Vernon, P. E. Auditory perception: 11 The evolutionary approach. British Joornal of Psychology, 1935, 25, (3), 265-281.

Vorce, F. W., Jr. The effect of simultaneous stimulation on vocal pltch accuracy. Unpublished doctoral disserlation, florida State University, 1964.

Welis, D. F. Vocal pitch training using a visual referent. Unpublished doctoral dissertation, University of Denver, 1964.

Werner, H. Comparative psychology of mental development, Rev. ed. New York: International Universities Press, Inc., 1973.

whipple, G, M, Studies in pitch discrimination. American Journal of Psychology, 1903, 14, 289-309.

Winer, B. J, Statistical principles in experimental design. Now York: MeGraw-Hill Book Co., 1962.

Wing, H. D. Tests of musical ability and appreciation. British Journal of Psychology Nonograph Supplements, hr. 27, second edition, 1968.

Wright, F. A. The correlation between achievement and capacity in mus 1c. Journal of Educational Research, 1928, 17, 50-56.

Wyatt, R. F. Improvability of pitch discrimination. Psychological Monographs, 1945, 58, nr. 2, 1-58.

Zwissler, R. N. An investigation of the pitch discrimination skills of first-grade children identified as accurate singers and those identifled as inaccurate singers. Unpublished doctoral dissertation, University of Callfornla, Los Angeles, 1971. 
APPENDIX A

AVERAGED SCORES: JUDGE A AND JUDGE K

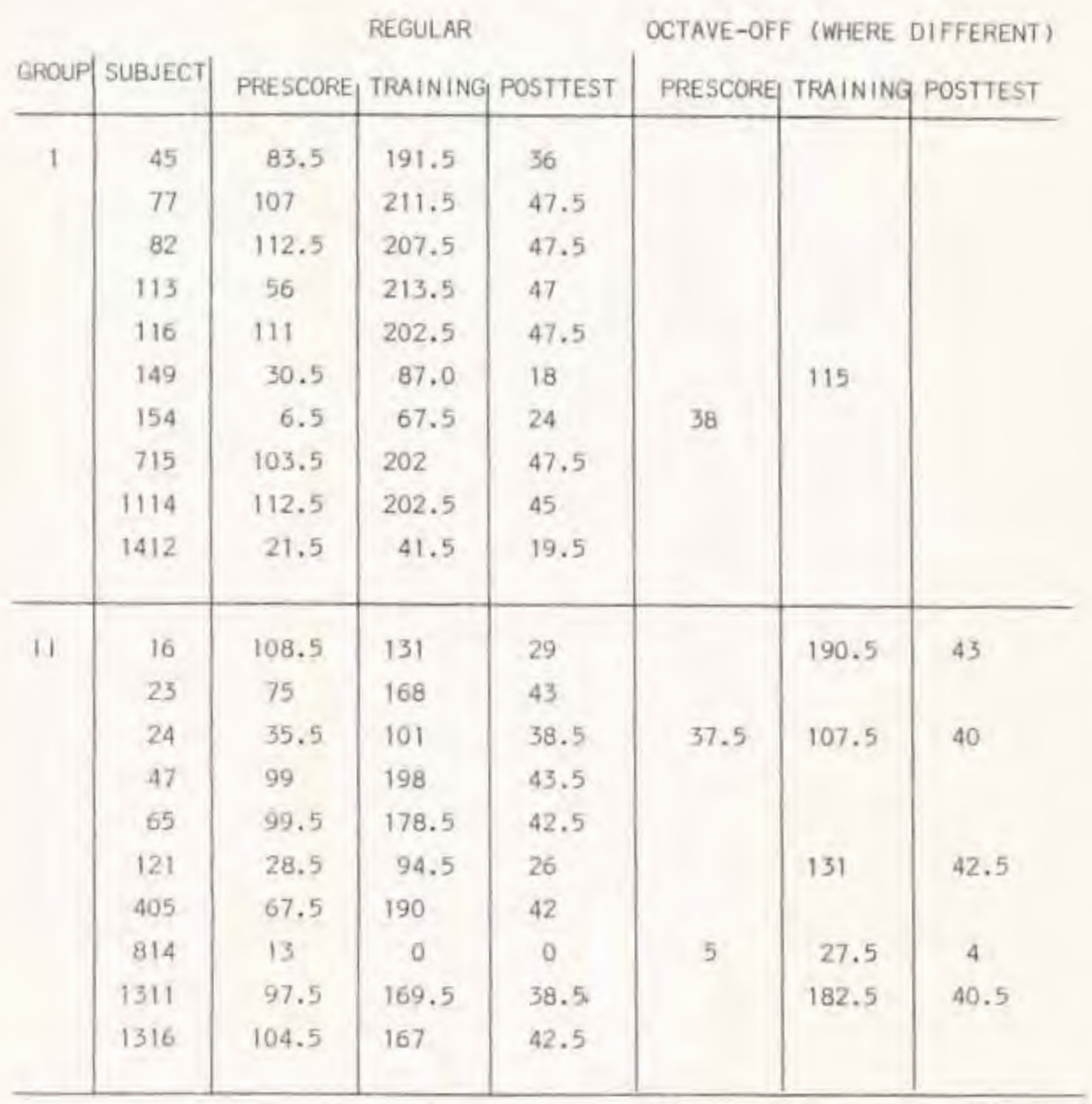




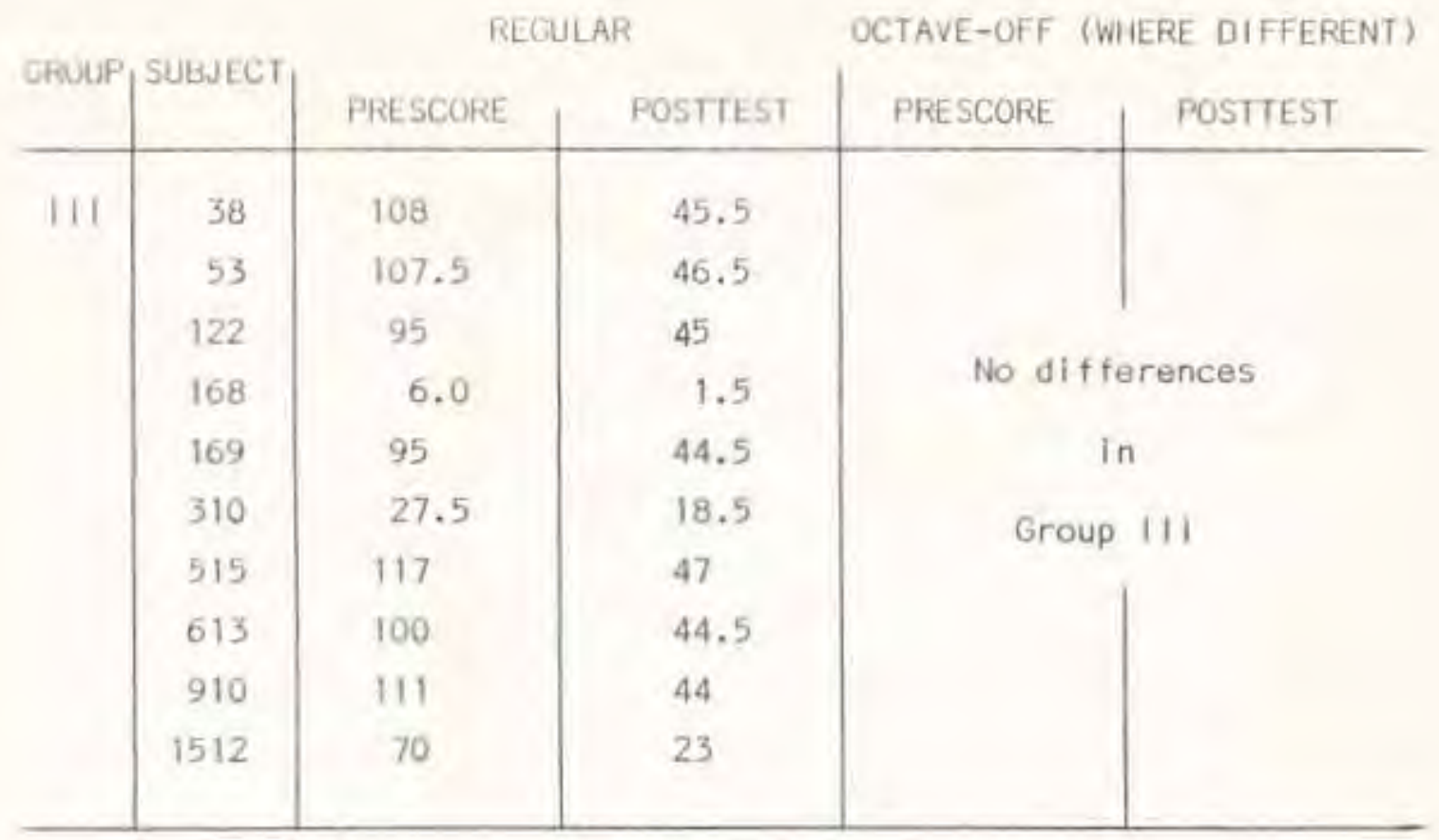


APPENDIX B

AVERAGED GROUP MEANS AND STANDARD DEVIATIONS JUDGE A AND JUDGE $K$

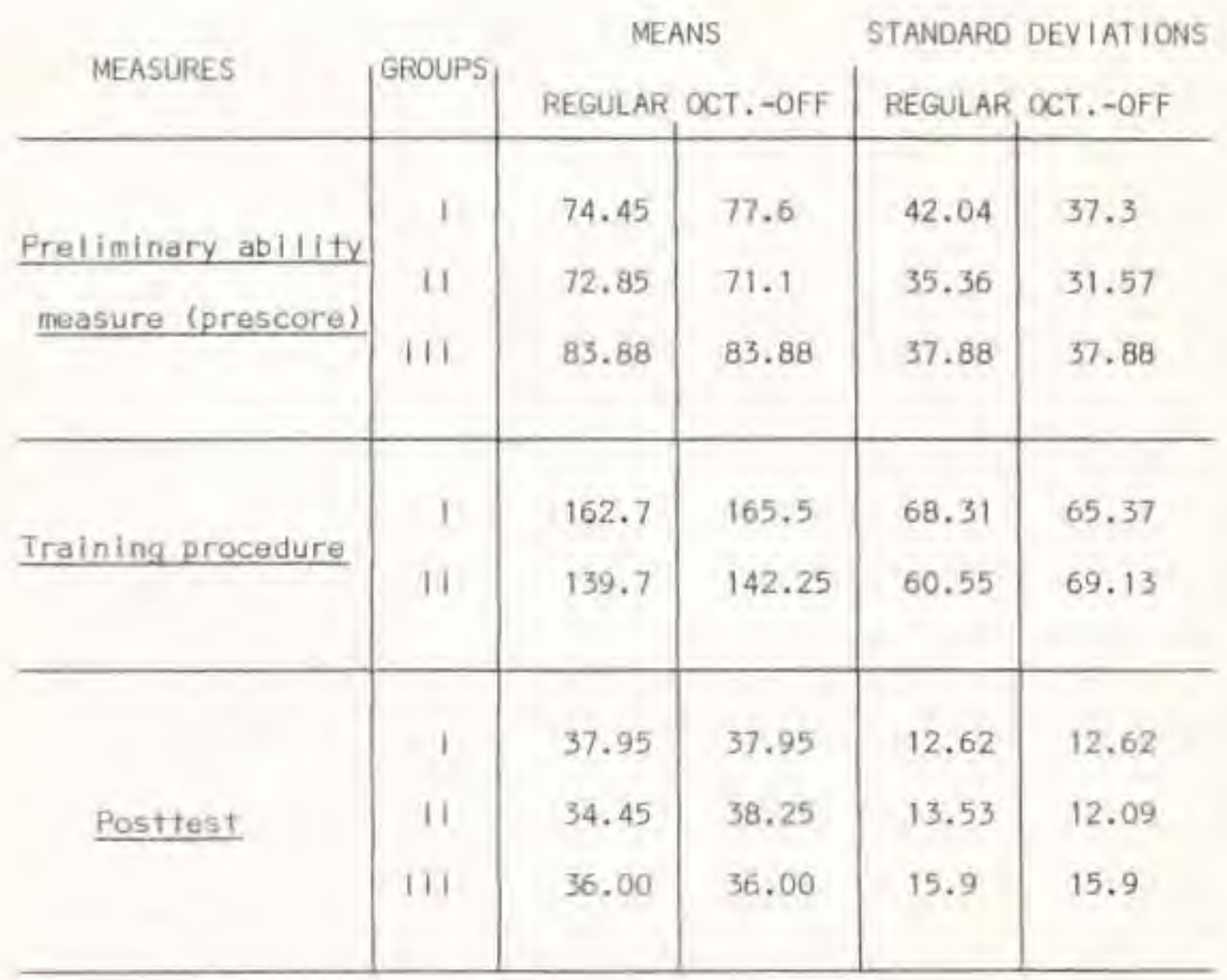




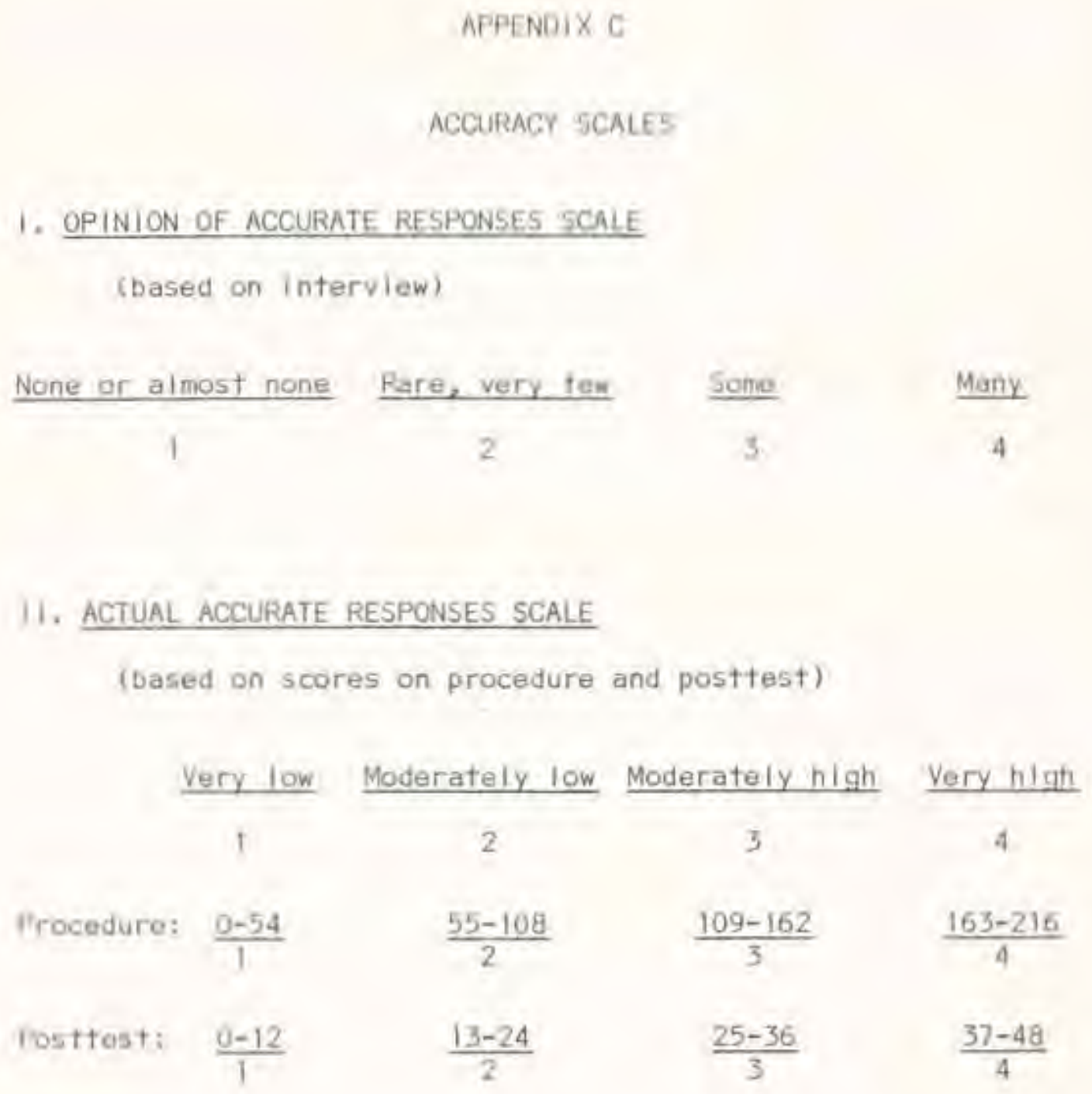


APPENDIX D

\section{INTERVIEW: SUGGESTED QUESTIONS}

COMMENTS ON EXPERIMENT

1. What helped the most? (Not asked Control group)

2. How clear were the Instructions?

3. Was It important to have no one in the room?

4. Did you find the preliminary measure (prescore) harder or easler than the rest?

5. In what ways?

6. How did you expect to do on this task before you started?

7. How do you think you actually did?

8. How did this make you feel?

\section{EARLY MUSICAL EXPERIENCES}

1. When and how did you learn you have trouble carrying a tune?

2. How did this realization make you feel at the time?

3. How did it make you teet as you were growing up?

4. How do you feel about this difficulty now?

5. What have you musical experiences been? (Choir, instruments)

6. How long dad you continue witheit?

7. What kind of feedback did you get?

8. Did you enjoy the experience? 
FAMILY AND MUSIC

1. Do your parents carry a tune accurately?

2. Do you romember efther of them singing to or with you as you were growing up?

3. Do or did your parents play any instruments? sing?

4. Can your siblings carry a tune?

5. Do any of them play an instrument, or did they as children?

6. Did your parents encourage you in your early musical axperiences?

7. How much music was there at home, on records, radio, i ive?

\section{ATTITUDES AND INTERESTS}

1. What was your attitude toward music as a chlld? What kinds?

2. What is your attitude now? What kinds?

3. Did you ever try to improve your singing ability? If so, how? 


\author{
APPENDIX E \\ TRAINING PROCEDURE AND POSTIEST: \\ TRANSCRIPTS OF TAPED INSTRUCTIONS, \\ TYPED INSTRUCTION CARDS, \\ CHARTS
}


TAPED INSTRUCTIONS: NON-VISUAL GROUP (I)

You are about to begin a practice session intended to improve your ablitity to vocally match pitches which you hear. If at any time the instructions are not clear, push the "stop" button on this cassette tape recorder and get the experimenter or her assistant.

In front of you is a special tape recorder called a Language Master and a pile of white cards, each of which has a strip of magnetic tape on the botforn. During the session, you will use one card at a time. The first two cards are for practice in the use of the machine. The remaining cards are for the actual practice part of the experiment. Each card has printed on it a letter representing the pitch which is recorded on the magnetic tape and which you will try to match.

Locate the slot running across the entire top of the Language Mastar. Durlng the sessions you are to place each card one at a fime Into the slot, starting at the right and pushing it left until it is caught by the rollers. Then it will mave by itself. On the left nalf of the card, words or a single pitch have been recorded. The right half is blank and at certoin points in the procedure, you will be asked to record your response there, that is, the words or the pitch of the model.

Notice the lever on the left side of the front of the Language Master. It is pointing to "listen." In order to record, you must turn it to "record" and hold it there during the entire second hal $f$ of the card, while you are singing, then release it. When I finlsh the Instructions 1 will say "try it now" and at that point you may push the "sfop" Dutton on this cassette, take the first practice card and 
Iry this procedure untll it's confortable, but please walt until i say "try it now." AT that point you will put practice card yl through once and just listen, put it through again and then imitate the words you just heard, while keeping the lever pointing to record. Please only use practice card one. After you are done put practice card $\# 1$ into a different pile from the others, push the "play" button on this cassette and continue with the instructlons. The procedure for practice card \#1 is also typed on a small index card. You may press "stop" and try it now.

In trying to match the pitches remember to relax your larynx to make a lower sound and tighten it to make a higher sound. Without recording, try now making the highest and lowest tones you can, using the vowel "ee," and notice the difference in tightness in your throat. You may now use practice card $\# 2$ to try the following procedure which you will be using during the actual experiment. Each step requires you to put the card through the Language Master again. After listening to these instructions, take time to read through the procedure which is typed on the large index card, and then try it out for about two minutes, after whlch the experimenter or her assistant will come in to signal the beginning of the regular practice session. Here are the instructions:

1. Insert the card, IIsten and imagine singing the pitch

2. Insert the card, Iisten, and sking along simultaneously with the model, using the vowel "ee."

3. Listen and sing along again.

4. Listen and imitate the pitch right after the model stops. 5-8. Listen and imitote again, four times in the same way, 
Feinserting the card each time.

9. After you've done the listening and imttating 5 times, reinsert the cards, Iisten, and right atter the model stops, furn the Language Naster lever to "record" and hold it there while you imitate the model.

10. Reinsert the card, ilsten, and then compare your own recorded pitch with that of the model.

11. Again reinsert the card, Ilisten and record.

12. Reinsert the card, IIsten, compare.

13. Now reinsert the card, listen and record, but do not compare. 14. Relnsert card, listen and record one last time.

Because the procedure is rather complicated, there is a chart for you to use during the whole sesslon. For each card, please put a checkmark in the appropriate box when you have completed that trial. The experimenter or her assistant is available to answer any questions. You may now push "stop" and begin.

Cood Iuck! 


\section{TAPED INSTRUCTIONS: VISUAL GROUP (II)}

You are about to begin a practice session intended to improve your abllity to vocally match pitches which you hear. If at any time the instructions are not clear, push "stop" on this cassette recorder and get the experimenter or her assistant.

In tront of you is a special tape recorder called a Language Master and a pile of white cards, each of which has a strip of magnetic tape on the bottom. During the session you will use one card at a time. The first two cards are for practice in the use of the machine. The remaining cards are for the actual practice perlod of the experiment. Each card has printed on it a letter representing the pitch which is recorded on the strip of tape which you wlll try to match. The first practice card has some words instead.

Locate the slot running across the entire top of the Language Master. During the session you are to place each card, one at a time into the slot, starting at the right and pushing it left until it is caught by the rollers. Then it will move by itselt. On the left halt of the card words or a single pitch have been recorded. The right halt is blank and at certain points in the procedure you will be asked to record your response there, that Is, elther the words or the pitch of the model,

Notice the lever on the left side_of the front of the Lanauade Master. It is pointing to "listen." In order to record you must turn it to "record" and hold it there during the entire second halt of the card, while you are singing, then release it. After I have finlshed with the instructions, when I say "try it 
now," pusf the "stop" button on the cassette, take the first practice card and try the following procedure until it is comfortable. Please do not try it yet, but rather, listen unfil I am finished with the instructions and say "try it now."

Put card $\# 1$ through the Language Master slot once and Just listen, then put it through agsin, IIsten and Imitafe the words you've just heard and record them while you're imitating them, keeping the lever pointed to "record." Please only use practice card \#1 and after you are done with it, put card \#1 in a different pile, push the "play" button an this cassette and continue with the instructions. These instructions are also printed on the small index card. You may press "stop" and try $1+$ now.

In trying to match the pitches, remember to relax your larynx to make a lower sound and tighten it to make a higher sound. Without recording, try now making the highest and lowest tones you can, using the vowel "ee" and notice the difference in the tightness of your throat. The machine with windows mounted on a cart in front of you is ealled a Straboconn, used to give feedback on pitch accuracy. There are twelve windows, one for each note of the chromatic scale. In each whdow there is a spinning disc, with a series of bands on it. One or more bands on the disc in a particular window will appear to stop spinning when the correspanding pitch is sung or played through the microphone located betore you on the desk.

Look now at the first window on the fop row, far left, this. is C sharp, while I sing C sharp. (sings C sharp, using "ee.") If I ging too low, or flat, the disc will appear to drift slightly to the left. It I sing too high or sharp, the disc will appear to dritt 
silightly to the right. Watch while I sing on pltch, then slightly flat with the C sharp. (Does so.) Now watch while I sing on pitch, then silghtly sharp with the C sharp. The Strobocono is intended to give you immediate feedback while you are imitating so you will know if you are singing close to pltch, too sharp, or too flat. Conslder your pitch to be sufficlently accurate when the band in the window seems to stop at least briefly, even if it wobbles due to a vibrato or wavering in your volce. Since the machine is very sensitive it will pick up very subtle changes in pitch. Even experienced singers have difficulty getting the band to stay steady. You should just aim at getting the band to slow down and if possible, to stop brlefly. For each card, be sure to check the name of the pitch printed on the card and locote this pitch on the stroboconn before starting the procedure. When you tirst seem to be slowing the band down, check the other windows too, to be sure the correct window is the darkest. It does not matter which band of the appropriate disc slows down. Vocal pifch includes overtones; that is, related pitches which will also make the stroboconn disc stop. Eut the black lines of the different bands will appear much fainter it you are hitting the overtone instead of the main pitch. Watch the windows for $C$ sharp and $G$ sharp as I sing $C$ sharp, and notice how both stop, but C sharp is darker. (SIngs C sharp.) Notice how this changes when $I$ sing $G$ sharp. (Does so.) During the session, once you've established that the band for the pitch you're trying to match is indeed the darkest one that's slowing down when you sing, focus your attention on it during the rest of the steps or triais for that card, and try to make it stop completely. Remember, it the band appears to drift to the loft your pitch is flat. Try to alter 
your pitch by increasing the tension in your larynx. If the band appears to drift to the right, your pitch is sharp. Try to relax your larynx somewhat, to try to tiatten the pitch. If your pltch is closer to another pitch than to the model's, the band in the window corresponding to this other pitch wlll appear to slow down or stop. If this happens, reinsert the card and continue with the standard procedure, trying to change your pitch.

During the practice, before the regular session you may take some extra time before reinserting the card, to try to alter your volce until it makes a band in the appropriate window stop or slow down. Notice how your volice affects the Stroboconn. During the regular session, try of alter your pitch Just during the time the card is golng through the Language Master.

Watch now while I sing $C$ sharp, then incorrectly imitate it. (Does so,) Did you see the third window from the left in the top row seem to stop? Watch again, C sharp (sings), tmitation (sings F sharp.) Now take practice card $\# 2$. On it is recorded a $C$ sharp. Follow this procedure, which is also printed on the large index card in front of you. Please listen to the whole procedure before trying to do it:

Note: Before inserting each card, check which pitch is printed on it and locate that pitch window on the stroboconn.

1. Insert the card into the Language Master, 11sten and imagine singing the pitch.

2. Reinsert the card, Iisten, but sing along with the model, using the sound "ee" while watching the Stroboconn and try to alter your volce to make the band in the approprlate window slow down or stop. 
3. Listen and sing alomg again.

4. Liston and imitate the model right after the model has stopped, always using the stroboconn to help you judge your accuracy. Try to alter your pitch so that it makes the band in the appropriate window stop or slow down.

5-8. Listen and imitate again, four more times in the saine way, reinserting the card each time.

9. After you have done the listening and imitating 5 times, reinsert the card, listen, and right after the model stops, turn the Language Master lever to "record" and hold it there while you imitate the model, still watching the Stroboconn.

10. Reinsert the card, listen, and then compare your own recorded pifch with that of the model.

11. Again insert the card, listen and record.

12. Reinsert card, 1isten, compare.

13. Now reinsert the card, listen and record, but do not compare 14. Reinsert card, listen and record one last time.

That's the entire procedure. Remember to always use the stroboconn to help you decide whether you are accurate, and the band slows Jown or stops, or you are too sharp and the band drifts to the right, or too flat and the band drifts to the left.

You may now fry practice card $1 / 2$ with the Stroboconn for about two minutes, after which the experimonter or her assistant will come in to signal the beginning of the regular practice session. If you have any questions at any polnt, please get the experimenter or her assistant, Because the procedure is rather complicated, there is a 
chart tar you to usa during the whole session. For each card, please put a checkmark. in the appropriate box when you have completed that trial. You may now push "stop" and begin. Good Luck:

\section{TAPED INSTRUCTIONS: CONTROL GROUP (III)}

You are about to begin an experimental session on vocal pltch matching. If at any time the instructions are not clear, push "stop" on the cassette tape recorder and get the experimenter or her assistant.

in tront of you is a special tape recorder called a Language Master and a pile of white cards, each of which has a strip of magnetic tape on the bottom. During the session you will use one card at a time. The first two cards are for practice in the use of the machine. The remaining cards are for the actual experiment. Each card has printed on it a letter representing the pltch which is recorded on the strip of tape and whlch you will try to match.

Locate the slot running across the entire top of the Language Master. During the session you are to place each card into the slot starting at the right and push it to the left until it is caught by the rollers. Then it will move by itself. On the left half of the cards, words or a single pitch have been recorded. The right halt is blank and at certain points in the procedure you wil be asked to record your response there, that 15, elther the words or the oitch of the model.

Notice the lever on the left side of the front of the Language Master. It is pointing to "ITsten." In order to record, you must turn it to "record" and hold it there during the entire second half 
of the card while you are singing or speaking, then release it.

When I have finished the instructions and say "fry it now" you

are to push the "stop" button on this cassette, take the first

practice card and try the procedure, but please wait until I say "try

it now." This procedure Is printed on a small Index card as well, in case you forget.

The first thing to do is to put the card through once and just listen to it. The put it through again and imitate the words you just heard while keepling the lever pointed to "record." Please only use practice card 1. You may do it two or three times it you need to, to become comfortable with the procedure. After you are done, place practice card one in a different pile and push the "play" button on this cassette recorder to continue with the instructions, You may press "stop" and try it now.

In trying to match the pitches, remember fo relax your larynx to make a lower sound and tighten it to make a higher sound. Without recording, try now making the highest and lowest tones you can, using the vowel "ee" and notice the difference in tightness in your throat.

I will now tell you the procedure you will be using for practice card 2 and the rest of the experimentai cards. If you have any questions, the experimenter or her assistant will continue to be available to answer them. After you feel comfortable with the procedure let the experimenter know and she or heir assistant will start the tape recorder for the experimental session itselt. The procedure for all the rest of the cards is printed on another small index card and I will let you know what it is now:

Insert the card, push it until it is caught by the nollers, 
Iisten to the model on the tirst halt of the card, and I mediately turn the lever to "record" and hold it there while you imitate the model, for the entire second half of the card. Reinsert the card and try the procedure again, Iistening to the first half and immediately imitating on the second half of the card, while holding the lever on "record." After you have done this the second time, go to the next card. In each case you are to listen and record two times for each card. When you have completed all the cards, please let the experimenter know that you are finished, You may now press "stop" and try the procedure with practice card 2 until you are comfortable with it, then signal the experimenter that you are raady to begin on the regular cards. Press "stop" now.

Good luck:

\section{TYPED INSTRUCTIONS}

\section{PROCEDURE FOR PRACTICE CARD I}

\section{(ALL GROUPS)}

1. Insert card in slot from rt. to left. Push until it catches. Let it go through and i isten.

2. Reinsert, listen, imitate the words you just heard, while the lever pointed to "record" only during the second halt of the card.

3. You may repeat this procedure a few times if needed, until you are comfortable with. it. The expefimenter is avallable to answer quastions.

4.Push "play" on the cassette to continue with instructions. 
PROCEDURE FUR PRACTIEL CARD 2

AND ALL CARDS DURING THE REGULAR SESSION

GROUPS I (NON-VISUAL) AND 2 (VISUAL)

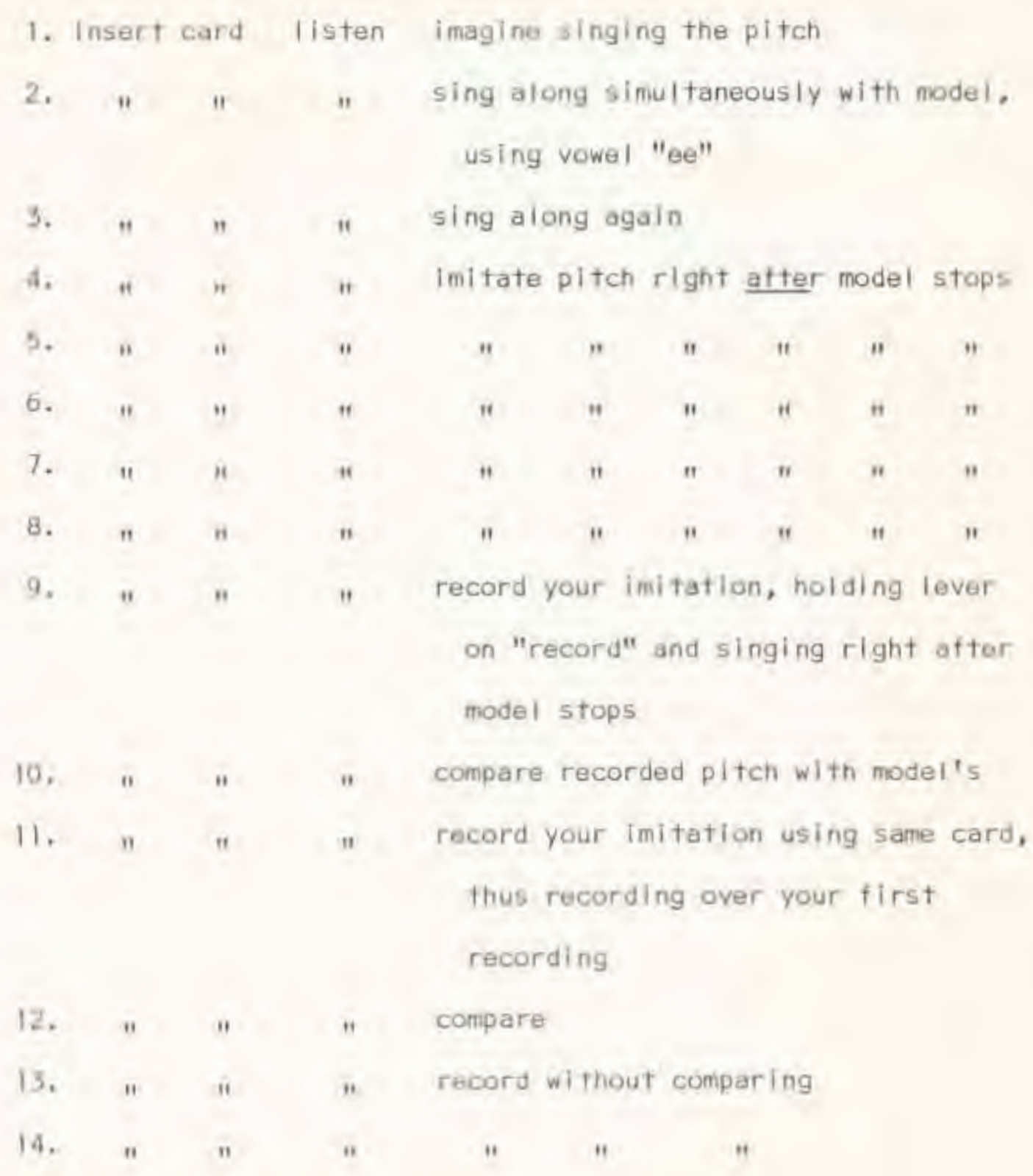


PROCEDURE FOR PRACTICE CARD 2

AND ALL CARDS DURING THE REGULAR SESSION

GROUP III

1. Insert card listen record your imitation, holding lever on "record" and singing right after model stops

2. Insert card listen record your imitation, using same card, thus rerecording over your first recording 
CHART, GROUPS I AND II

\begin{tabular}{l|l|l|l|l|l|l|l|l|l} 
& D & A & C & F & G & E & C & G & \\
\hline Listen-Imagine & & & & & & & & & \\
\hline Listen-Sing olong & & & & & & & & & \\
\hline Listen-Sing along & & & & & & & & & \\
\hline Listen-Imitate & & & & & & & & & \\
\hline Listen-Imitate & & & & & & & & & \\
\hline Listen-Imitate & & & & & & & & & \\
\hline Listen-Imitate & & & & & & & & & \\
\hline Listen-Imitate & & & & & & & & & \\
\hline Listen-Record & & & & & & & & & \\
\hline Listen-Compare & & & & & & & & & \\
\hline Listen-Hecurd & & & & & & & & & \\
\hline Listen-Campare & & & & & & & & & \\
\hline
\end{tabular}


CHART ; GROUP III

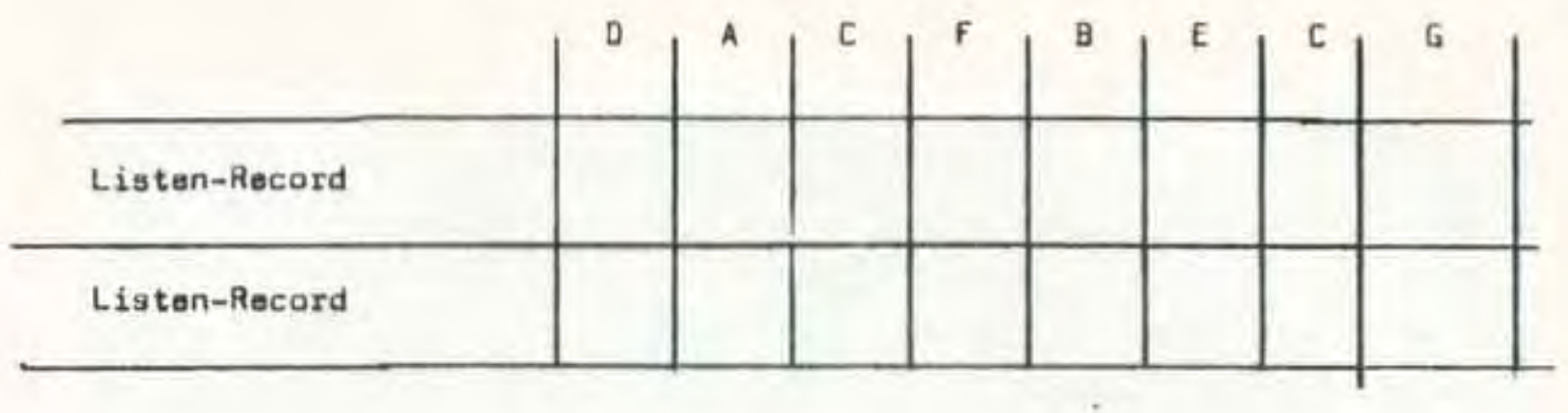


APPEN DIX F

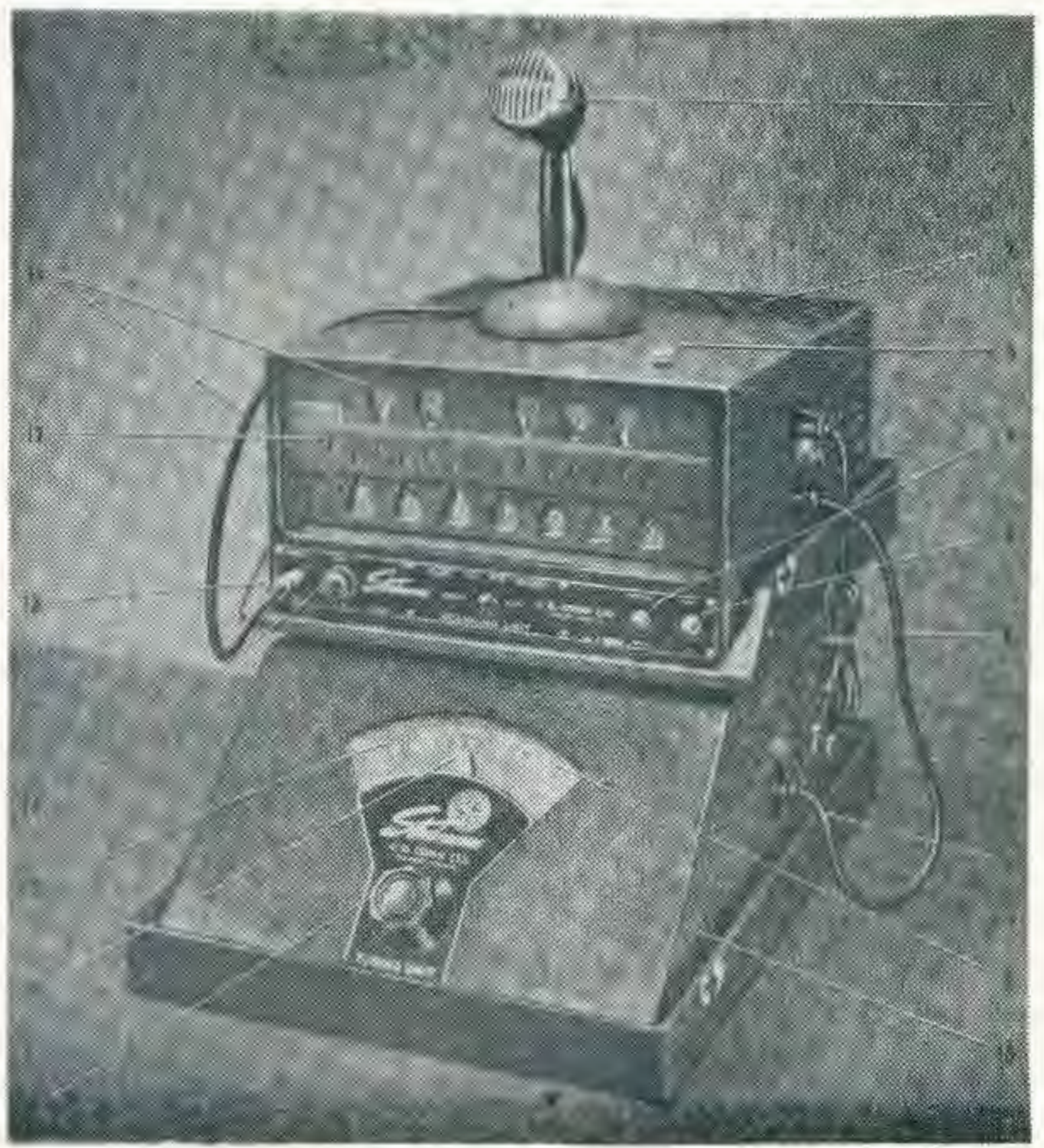

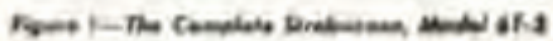

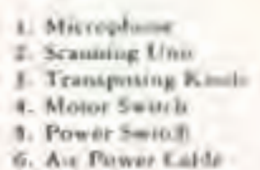

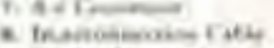

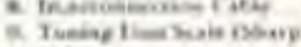 \\ intei \\ 16. Tanies Vea \\ ii. Aons-s seire: \\ paca mos
}

12. Ker Mansurs 15 iedion 19. Aticruplases Casasstim

14. Valume 5onaral

is. Tobiens Scale Mlat Statr)

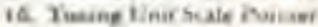

is. Jenaug Kasib 
APPENDIX G

RANKS ON AUDIOGRAMS AND PRESCORES

\begin{tabular}{|c|c|c|c|}
\hline Subject & Rank* on & audiogram & Rank* on prescore \\
\hline 77 & & 3 & 8 \\
\hline 82 & & 11 & 2.5 \\
\hline 113 & & 7.5 & 18 \\
\hline 149 & & 15 & 20 \\
\hline 154 & & 22.5 & 25 \\
\hline 1114 & & 26 & 2,5 \\
\hline 1412 & & 13 & 23 \\
\hline 16 & & 11 & 5 \\
\hline 24 & & 15 & 19 \\
\hline 47 & & 1 & 12 \\
\hline 65 & & 24.5 & 11 \\
\hline 121 & & 3 & 21 \\
\hline 405 & & 5 & 17 \\
\hline 814 & & 15 & 24 \\
\hline 1311 & & 20.5 & 13 \\
\hline 1316 & & 24.5 & 9 \\
\hline 38 & & 17.5 & 6 \\
\hline 53 & & 7.5 & 7 \\
\hline 122 & & 17.5 & 14.5 \\
\hline 168 & & 3 & 26 \\
\hline 169 & & 7.5 & 14.5 \\
\hline 310 & & 20.5 & 22 \\
\hline 515 & & 7 & 1 \\
\hline 613 & & 22.5 & 10 \\
\hline 910 & & 19 & 4 \\
\hline 1512 & & 11 & 16 \\
\hline
\end{tabular}

